\title{
Discussing and Analyzing "Maritime Cohesion" in MSP, to Achieve Sustainability in the Marine Realm
}

\author{
Stella Sofia Kyvelou ${ }^{1,2, *}$ and Dimitrios Ierapetritis ${ }^{1}$ \\ 1 Department of Economic and Regional development, School of Sciences of Economics and Public \\ Administration, Panteion University of Social and Political Sciences, 136, Syggrou Ave., \\ 17671 Athens, Greece; d.ierapetritis@panteion.gr \\ 2 Society for Urban Ecology, 5020 Salzburg, Austria \\ * Correspondence: kyvelou@panteion.gr; Tel.: +30-210-923-6206
}

Received: 29 April 2019; Accepted: 19 June 2019; Published: 22 June 2019

\begin{abstract}
Whilst the Sustainable Development Goal (SDG) 14 promotes the conservation and sustainable use of the seas, oceans and marine resources for sustainable development, decisions in ecosystem-based Maritime Spatial Planning (MSP) follow annoying and costly trade-offs and this may negatively impact its acceptance. To address conflicts and cumulative impacts and favor, as much as possible, interfering of marine activities, positive coordination and win-win options, it is necessary to develop integrated and cohesive planning approaches and new management tools. In this article, a conceptual framework of "maritime cohesion" is being developed mostly applicable to peopled and crowded seas and a set of relevant indicators to assess it, is proposed. It is based on the triple-model of interdependent components such as "maritime spatial efficiency", "maritime spatial quality" and "maritime spatial identity", taking into account the "territorial cohesion" equivalent, promoted by the Cohesion Policy. Then, in order to broadly analyze the "spatial efficiency" component, the "multi-use" concept and management tools, recently given particular emphasis by EU Blue Growth Strategy, are examined thoroughly, using the relevant literature. This article highlights constructive use of "maritime cohesion" with the multi-use MSP paradigm as key part of "maritime cohesion" narrative and posits that its huge and extensive potential can stimulate dynamic, collaborative, cohesive and assemblage thinking in the MSP process and be the "spearhead" to balance economic, social, environmental and cultural aspirations in maritime planning to achieve sustainability in the marine realm.
\end{abstract}

Keywords: Maritime Spatial Planning; cohesion thinking; maritime cohesion; multi-use concept; resilience; sustainable development

\section{Introduction}

Whilst the Sustainable Development Goal (SDG) 14 promotes the conservation and sustainable use of the oceans, seas and marine resources for sustainable development [1,2] the concept, practice and emerging management responsibility of maritime spatial planning (MSP) is gaining ground worldwide as a trade-off procedure. MSP is directly related to the marine critical natural capital degradation, the current demands for the ever-increasing exploitation of marine resources and the emergence of conflicts between traditional and new uses of marine space. Competing claims for marine allocation are, potentially, home for conflicts. Still, they may alternatively lead to joint benefits if intelligent and creative planning concepts that involve co-location and assemblages of uses are sought, taking into account that not all uses are compatible with each other [3,4] and that complexity results from the potential co-existence of traditional activities (fisheries, maritime traffic or even military uses) with the new blue growth industries (marine aquaculture, wind farms, sea bed mining etc.). 
Decisions in MSP follow annoying and costly trade-offs and this is a condition that may negatively impact its acceptance. The alternative is win-win decisions that rarely occur in current MSP procedures [5]. To address conflicts and cumulative impacts, and as much as possible, favor win-win options, it is necessary to develop integrated and cohesive planning approaches and new management tools. In this article, a conceptual framework of "maritime cohesion" mostly applicable when elaborating Maritime Spatial Plans for peopled and crowded seas is being developed and a set of relevant indicators to assess it, is proposed. It is based on the triple-model of "maritime spatial efficiency", "maritime spatial quality" and "maritime spatial identity", taking into account the "territorial cohesion" equivalent. However, adaptation to the specificities (biophysical environment, dynamic nature, peculiar property rights etc.) and complexities of the marine space [6-8] is needed. Moreover, it should not be overlooked that marine spatial allocation is not only a matter of increasing claims for marine space by both the traditional and the new Blue Growth related marine uses, but is also governed by political and geopolitical struggles.

To further analyze the "spatial efficiency" component, this paper builds on the multi-use approach, which is a creative and innovative solution that can favor positive coordination and win-win options [9], provided that MSP follows a nexus, assemblage [10] and resilience thinking [11] perspective.

This article examines insights from the relevant literature focusing on how the "multi-use concept" can be efficiently integrated in Maritime Spatial Planning and what site-specific and practical implications can result from this integration, especially in regions that are peopled [12] and crowded $[13,14]$ due to their specific geographical context (e.g., poly-insular and micro-insular areas in Europe) and the density of marine activities (both traditional activities such as fishing, shipping, tourism and new ones such as aquaculture, wind farms, but also underwater cultural heritage).

The "multi-use concept" is encountered in different forms in the literature. The prevailing ones are a: the well-known multi-use platforms (MUP) [3,15-24] and b: the multi-use of space (MUS) [15,25-31], meant as the combination of a series of marine industry sectors aiming to produce complementarities resulting in mutual benefits and surplus, through co-location and common infrastructure but without a common platform.

The term "multi-use maritime spatial planning" (MU MSP) is rarely met in the literature [32-36] and the current article focuses on the idea that MU MSP is a key vehicle towards cohesive planning and for introducing a new concept in sustainable development of the marine space, namely the concept of "maritime cohesion" [36]. Although the Marine Spatial Planning Directive (EC, 2014) encourages, in principle, "multi-purpose" uses within national policies and legislation, the existing literature $[31,33,34]$ shows that relevant institutional settings on a national level are, with only a few exceptions [31,37], insufficient to encourage the co-location process, and planners rarely consider this concept as a "must" for the elaboration of Maritime Spatial Plans. However, the idea of the multiple use of marine space was cited as early as in 2009 by Douvere [38], while examining the marine spatial planning progress. She distinguished multiple-use MSP, especially where density of uses is prevailing and conflicts among users and the environment are apparent, for example, in the North Sea. Of course, zoning was at that period, the key spatial planning tool and the basis of the management strategy for conservation.

Being a novel management feature in MSP process, "multi-use" is progressively more and more considered in areas where intensity of uses occurs, e.g., in the North Sea or in the Eastern Atlantic [26,32,37]. Jentoft and Knol [37] refer to this as a "peaceful co-existence" and give the example of the Dutch MSP approach that was revised (IDON 2011) so as to encompass multiple uses in the same marine area (water column). In the North Sea, exclusion through zoning is not the first option in the MSP procedure, as it is only used if possibilities of multiple use are exhausted, while at the same time cumulative impacts of multiple uses on the environment are always a concern [37]. Christie et al. [32] using the example of UK waters, suggest a systematically organized approach to balance competing demands and resolve potential conflicts during the MSP process. They define the setting of concurrent activities in space and time by MSP as "co-location" and note that this is developing as an advantageous tool toward confronting spatial conflicts in the UK inshore and offshore waters [39], concluding that the 
success and extent of co-location schemes are site-specific and that their scope and likelihood should be evaluated at the very beginning of the planning procedure. An important highlight of their insights is that adaptive management is absolutely necessary in order to successfully proceed to co-location and that given the scientific and commercial uncertainties, pilot projects and ongoing monitoring is needed to determine if co-location is feasible and operational. Zanuttigh et al. [40], analyzing realized MU platform related case studies in France, Spain, Denmark, Ireland, Germany and California, argue that the co-location of wave energy and wind farms is effective since it increases power production and opt for fostering the development of synergies with other uses such as transportation, aquaculture, gas platforms etc.

\section{Materials and Methods}

To pave the way towards a cohesion related conceptual framework in MSP, this article is structured around the following steps:

Firstly, identifying insights from visionary and methodological programs and projects focusing on integration and coherence of MSP between countries of the same sea-basin. Even if the "maritime cohesion" as meant in this paper does not coincide with "integration" or "coherence", there are methodological lessons to be learnt and useful indicators to be studied in these projects.

Secondly, this article focuses on the "spatial efficiency" component and studies insights from realized co-location in different sea-basins and national marine waters, through a literature review that includes also projects and policy reports (see Section 2.2 below). Concurrently, the identification of several key characteristics and key paradigms of multi-use MSP were identified, leading to a new definition for multi-use MSP, which is the dominant management model to follow in order to achieve "maritime spatial efficiency".

The above research materials supported the elaboration of a "maritime cohesion" conceptual framework with an ambition to initiate a cohesive and assemblage thinking [10] for the marine space, especially in peopled and crowded seas with particular socio-cultural features. The idea is about the transposition of the "territorial cohesion" concept in the dynamic and changing marine environments. For the concept of "territorial cohesion" there is a huge body of literature that was partly examined, since papers $[6,7,41-48]$ were selected depending on their potential contribution to the formation of the proposed concept and term of "maritime cohesion" and relevant assessment indicators.

The authors believe that similarly, and in a complementary use to "territorial cohesion", "maritime cohesion" can be decisive for planning both the economy and the environment (natural marine ecosystems as well as socio-cultural systems) and can shape an integrated maritime spatial planning paradigm including economic, social, environmental and cultural aspirations, promoting both economic efficiency [7], social $[49,50]$ and spatial equity $[6,51]$.

\subsection{Insights from Key Integration Related Projects to Inform a Cohesive MSP}

There are several visionary and methodological programs and projects focusing on MSP Integration. One of these is the EU-FP7 MESMA project (2009-2013), which focused on the so-called "Spatially Managed Areas" (SMAs), meaning areas where an MSP framework is either in place or is being developed in order to achieve conservation targets for marine ecosystems through the management of the cumulative pressures of different internal or external sectoral activities, including geohazards and climate change related threats. It is thus mainly concerning the Ecosystems and Biodiversity component—as presented in the "maritime cohesion" framework initiated in this paper below-and not the broader socio-ecological, economic and market related contexts. The MESMA framework provides guidance on the selection, mapping and assessment of ecosystem components and human pressures, using a quantitative natural science approach [52] rather than a planning one. Consequently, there are lessons to be learnt from this project, mainly from the bio-physical indicators and those concerning pressures on marine ecosystems. 
The transnational BaltSeaPlan Vision 2030 "Towards the sustainable planning of Baltic Sea space" [8], is mostly governed by a "maritime cohesion" thinking for the Baltic Sea space. The vision, linked also to national MSP, is part of an integrated approach to MSP across scales, expected to be translated into practice by 2030. Economic prosperity, social well-being and a healthy and resilient Baltic Sea ecosystem are the elements of a real "maritime cohesion", under the umbrella of sustainability, and MSP is a tool to secure them. Planners are attributed the role of custodians of the integrity of the ecosystem by minimizing impacts of sea uses. They target a "frugal" use of space, which is a term rarely met in the marine realm, compared with the urban environment [53]. "Spatial efficiency" [8] is fully recommended along with sparing location of uses, concentration and interdependence between them, promotion of co-uses, synergies and multiple spatial use. Planning is encouraged to encompass connectivity across space and time, between the different elements such as shipping lanes, ports, habitats etc. and between the present and the future. Transnational connectivity structures are planned at the pan-Baltic level and are given due regard in national maritime spatial plans. Planners rely upon commonly agreed, long-term environmental, economic and social quality objectives and targets for the whole sea-basin. They also acknowledge place-based priorities.

Moreover, the BONUS BALTSPACE project (2015-2018) [54] also provides an interesting approach in defining integration and exploring its challenges and implications for MSP processes, presenting it as a multi-dimensional concept. It is widely acknowledged that integration is a key element for MSP and the project focuses on key integration challenges, such as integration between policies and sectors, multi-level and transboundary integration, stakeholder and knowledge integration, concluding that the most important is the latter.

\subsection{The Focus on the "Spatial Efficiency" Component in MSP Processes}

Specifically for increasing "maritime spatial efficiency" [7,30], the European Commission funded many multi-use related projects in the 2000s, demonstrating a strong commitment to further investigate sustainable multi-uses with a focus on offshore seas and oceans. This is reflected in the initiation of major projects, either completed or ongoing (Table 1). The examination of the projects' conclusions shows that there is certainly great potential in the ability of the various key paradigms of MU MSP to successfully serve "maritime spatial efficiency". It is worth mentioning the MERMAID project that, focusing on geographically representative offshore study sites and in compliance with EU energy and aquaculture strategies, developed models for next generation, offshore, multi-use platforms dedicated to energy extraction, transport and aquaculture. It investigated optimization prospects of ocean space, environmental impacts and energy production, addressing cumulative impacts of MU platforms but also good practices and development strategies for their installation, maintenance and operation as well as environmental and economic feasibility (see Table 1). The TROPOS FP7, a highly technology-driven, added-value project, developed a flexible, floating, modular multi-use platform system, adaptable to diverse geographic contexts, which in this case was adapted to deep water conditions and focused on the Mediterranean Sea and some low-latitude tropical and sub-tropical regions. It follows a market-oriented approach providing solutions to increase the market impact, including new local business activities such as renewable energy, shipbuilding, short-distance shipping and food production. The innovative design of a multi-use, open-sea platform as an alternative to ensure food security and energy supply, provided these are done ethically, was also the focus of the FP7 H2Ocean project. The project emphasized the collaboration with local communities and stakeholders, reducing competition with local fishermen. Its originality mostly relies on the Ethical and Social Impact Assessment Plan recommended and training is foreseen to facilitate the access of the coastal community to energy and aquaculture related jobs. The EU-H2020 MARIBE Project identified potentialities of MU in the offshore economy, considering future intensification, diversification and further offshore expansion of marine and coastal activities. Technological and non-technological challenges and sustainable business models were addressed. The project concluded that co-location is crucial for smarter, more sustainable and less disruptive sea use and developed cross-sectoral 
projects and sectoral combinations with synergistic potential, working with stakeholders to encourage partnerships and cooperative action plans. It promoted MUS with a view to strengthening the new and emerging Blue Growth Industries, also targeting job creation [15].

Last but not least, the H2020 MUSES Project ("Multi-Use in European Seas") compared the potential maritime multi-uses on a European sea-basin scale and revealed substantial peculiarities even if sectoral economic data on a national level was not taken into account [55]. The project revealed disparities between Northern and Southern European countries with the first-mentioned endowed with renewable ocean energy activities and offshore wind farms as main drivers of blue growth and co-location activities, and the latter mostly hosting smart co-locations of emerging and traditional maritime economic activities, with tourism being the main income source in these regions. The blue growth-oriented MUSES action plan presented sustainable blue growth opportunities, emphasizing the promotion of technological achievements in Northern European countries mainly as far as combinations with offshore energy installations are concerned. It emphasized the development of new technologies and cross-sectoral synergies in both developing and declining sectors and the contribution of multi-use to enable blue growth in disadvantaged areas across Europe such as rural and remote insular territories, reopening the discussion [56] on small-scale uses like pescatourism, as driver of diversification of fishers' activities to create complementary sources of income. Potential multi-use combinations were identified (e.g., underwater cultural heritage $(\mathrm{UCH})$ and tourism activities) that may also provide funding (e.g., through taxation) for UCH or nature conservation while expanding alternative tourism offers [57]. Capacity building of local stakeholders was revealed, as opposed to actions in the energy sector presenting high level and cutting-edge capacity. The project, governed by a strong blue growth thinking, although neglecting regional and sectorial disparities in terms of productivity, explored the sectors with the highest potential for MU resulting in tourism-driven multi-use combinations (e.g., pescatourism) and the reuse of Oil and Gas decommissioned platforms.

Recently $(2017,2018)$, two new EU projects were approved and are ongoing, namely the H2020 Space@Sea [58] and the "Blue Growth farm" [59] projects. The first one seeks to develop a standardized and cost-effective modular island with low ecological impact at sea and the latter to design a multi-purpose offshore floating platform co-hosting aquaculture and wind and wave energy, together with testing and certifying the design by proceeding to the construction and sea deployment of a pilot scale platform.

The above projects provide valuable insights to update MSP processes on different ecological environments and territorial scales and Table 1 summarizes the factors and the diverse foci. However, the MUSES project is the most prominent one with regard to the scope of the current article, since it is inspired by territorial thinking and has explicit territorial references. It repeated what was evoked by previous ESPON projects [60], that blue economic activities are strongly interrelated to the land and vice-versa and this applies also to landlocked regions that can be significantly affected by maritime activities. The North-South divide was also revealed concerning opportunities of intensive blue growth which is a cohesion related issue in Europe. Similar to this was the result of the ESPON ESaTDOR project that through a typology of maritime regions in Europe revealed that the most intense maritime activity, either in flows or economic terms, is concentrated in the traditional European core or European pentagon, along with some other regional hubs throughout Europe [60]. 
Table 1. Maritime spatial planning (MSP) related key factors addressed by major EU funded multi-use platforms (MUP) and multi-use of space (MUS) related projects. Source: Own elaboration by authors.

\begin{tabular}{|c|c|c|c|c|c|c|c|c|c|c|}
\hline $\begin{array}{l}\text { Projects/Completion } \\
\text { or Starting Year }\end{array}$ & $\begin{array}{c}\text { Focus } \\
\text { (Sectorial/Strategic } \\
\text { Thinking/Other) }\end{array}$ & $\begin{array}{l}\text { Geographic } \\
\text { Coverage } \\
\text { (Case-studies) }\end{array}$ & $\begin{array}{l}\text { Economic/Environmental } \\
\text { Feasibility }\end{array}$ & $\begin{array}{c}\text { Minimization } \\
\text { of } \\
\text { Environmental } \\
\text { Impact }\end{array}$ & $\begin{array}{l}\text { Resource } \\
\text { Efficiency }\end{array}$ & $\begin{array}{c}\text { Spatial } \\
\text { Efficiency }\end{array}$ & Mobility/Flexibility & $\begin{array}{c}\text { Territorial } \\
\text { Reference/Adaptation } \\
\text { to Regional } \\
\text { Specificities }\end{array}$ & $\begin{array}{l}\text { Stakeholders/Community } \\
\text { Involvement }\end{array}$ & $\begin{array}{c}\text { Relevant Articles } \\
\text { or Websites (Incl. } \\
\text { in the } \\
\text { References) }\end{array}$ \\
\hline MERMAID/2014 & $\begin{array}{c}\text { Sectorial } \\
\text { Aquaculture/Renewable } \\
\text { Energy }\end{array}$ & $\begin{array}{l}\text { Baltic Sea/North } \\
\text { Sea/Atlantic } \\
\text { Ocean/Mediterranean } \\
\text { Sea }\end{array}$ & 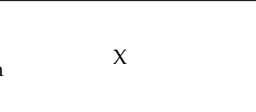 & $x$ & $x$ & $x$ & - & - & - & {$[20,21,41]$} \\
\hline TROPOS FP7/2014 & $\begin{array}{l}\text { Technical/Technological } \\
\text { Market-oriented } \\
\text { Regional focus }\end{array}$ & $\begin{array}{l}\text { Mediterranean, } \\
\text { Tropical and } \\
\text { Sub-Tropical } \\
\text { Regions }\end{array}$ & $x$ & $\mathrm{x}$ & $\mathrm{x}$ & $x$ & $x$ & $x$ & $x$ & [61] \\
\hline H2Ocean/FP7/2012 & $\begin{array}{c}\text { Ethical/Food } \\
\text { security/Energy } \\
\text { supply/Novel approach } \\
\text { for transmitting } \\
\text { offshore RES. }\end{array}$ & $\begin{array}{l}\text { North Atlantic, } \\
\text { North Sea and } \\
\text { Mediterranean }\end{array}$ & $\mathrm{x}$ & $\mathrm{x}$ & - & - & - & - & $\mathrm{x}$ & [23] \\
\hline MARIBE/EU-H2020/2016 & $\begin{array}{l}\text { Blue growth } \\
\text { Focus/business-oriented }\end{array}$ & $\begin{array}{l}\text { Mediterranean, } \\
\text { Baltic, Atlantic } \\
\text { and Caribbean }\end{array}$ & - & - & $\mathrm{x}$ & $\mathrm{x}$ & - & - & $x$ & {$[15,27,61]$} \\
\hline MUSES/EU-H2020/2018 & $\begin{array}{l}\text { Blue growth } \\
\text { thinking/Sea-basin } \\
\text { oriented//no sectoral } \\
\text { national data used. }\end{array}$ & $\begin{array}{c}\text { European } \\
\text { Sea-basins--North } \\
\text { Sea, Atlantic Sea, } \\
\text { West Coast of } \\
\text { Scotland Sea, } \\
\text { Baltic Sea, } \\
\text { Swedish and } \\
\text { Danish waters, } \\
\text { Med. Sea } \\
\text { (Northern } \\
\text { Adriatic and } \\
\text { Aegean Sea) }\end{array}$ & $\mathrm{x}$ & $\mathrm{x}$ & $\mathrm{x}$ & $\mathrm{x}$ & - & $\mathrm{x}$ & $x$ & {$[25,26,29,55,60]$} \\
\hline $\begin{array}{c}\text { H2020 } \\
\text { Space@Sea/Started } 2017\end{array}$ & $\begin{array}{c}\text { Modular } \\
\text { design-oriented }\end{array}$ & Global & $\mathrm{x}$ & $\mathrm{x}$ & - & $\mathrm{x}$ & $x$ & - & - & $\begin{array}{l}\text { https://spaceatsea- } \\
\text { project.eu }\end{array}$ \\
\hline $\begin{array}{l}\text { Blue Growth } \\
\text { farm/started } 2018\end{array}$ & $\begin{array}{l}\text { Novel technological } \\
\text { design and } \\
\text { management driven } \\
\text { Multi-use insights }\end{array}$ & $\begin{array}{l}\text { Global and in } \\
\text { differing sea and } \\
\text { wind energy } \\
\text { conditions. }\end{array}$ & $\mathrm{x}$ & $\mathrm{x}$ & $\mathrm{x}$ & $\mathrm{x}$ & $\mathrm{x}$ & $\mathrm{x}$ & $\mathrm{x}$ & $\begin{array}{l}\text { http://www. } \\
\text { thebluegrowthfarm. } \\
\text { eu }\end{array}$ \\
\hline
\end{tabular}




\subsection{MU Defining Characteristics}

The aforementioned MUSES Project (2018), explicitly identifying all possible combinations of marine uses in a co-location perspective, concludes that there is no universally acknowledged definition of "multi-use" and inspired by definitions used in other initiatives defines multi-use of marine space (MUS) as a "joint intentional use of resources in close geographic proximity ... this can involve either a single user or multiple users". The definition provided, characterizes MU as an "umbrella term" covering a series of different combinations of uses in the marine space. It is defined through the distinction between "exclusive resource rights" and "inclusive sharing of resources by one or more users" thus focusing, obviously and in a restrictive manner, on the kind of exploitation rights of the different uses/users, making no reference to their different settings, cooperative models and interactions, in other words, to their constellations [62] and assemblages.

However, through the literature review a series of challenging characteristics of the multi-use MSP process are evident. Almost all authors agree that MU MSP is governed by increased complexity [34], since it involves different actors and groups with different interests and different perceptions of the sea space. There is, also, a subjective understanding and different considerations about opportunities or risks. The dilemma between high productivity and an ecosystem-based approach with minimized risks is also evident and there is often a lack of political will $[20,35]$ or political consensus to promote multiple ocean uses, often despite the strong interest of the representatives of the research community [22]. Furthermore, public acceptance and political will are rather localized depending on the specific sectors (renewable energy, wind farms, marine aquaculture) which gives a head start to Northern in relation to Southern Europe, where there are many traditional sectors involved that might not receive sufficient political support.

In addition, different social obstacles have been reported. For example, there is the risk for MUP developments to be in conflict with both the local fishing community, which is a traditionally significant stakeholder in the marine realm, and the commercial and tourism maritime routes [20]. Of course, conflicts largely depend on the specific combination of activities in a multi-use setting and also on their specific vertical location in the marine water column. Depellegrin et al. [25] mention the example of floating offshore wind energy to be implemented in deep waters, at a greater distance from the coasts, thus avoiding to a great extent any conflicts with coastal tourism and other leisure activities. Another example is the one of aquaculture that despite its contribution to food supply, may create serious conflicts with already existing traditional activities such as, in most cases, fisheries and tourism. To resolve such conflicts, specific decision-support tools are being developed to facilitate the assessment of planning scenarios in a context of a multi-use setting [62].

On the other hand, the idea to combine new emerging industries, e.g., offshore wind farms and mariculture, in a multi-use perspective is reported as an opportunity that can potentially create synergies between the different activities and rationalize operating processes in the sense of optimizing labor capacities and achieving resource savings [3]. Besides, the creation of multi-purpose marine areas within the same ocean territory may provide an opportunity in light of and in contrast with the permanent installation of single offshore utilization patterns [3]. The increases of cross-sectoral and cross-border cooperation are also identified. The latter is realized through cabling, oil ducts, auxiliary routes, wind farm installations, etc. Finally, it is considered as a tool that can be useful in protecting the environment since early expression of stakeholders' engagement and commitment for a multi-purpose use of space shows a favorable attitude towards the environment.

Benefits from multi-use MSP are two-fold, both public and private [63]. Reduced footprint of the assemblage of more economic activities, which means spatial efficiency, and reduction of losses in terms of the value of ecosystem services due to incompatible uses of sea space are some of the public benefits. On the other hand, the private sector can benefit from the cost savings due to shared use during the planning, legal and permitting procedures. Moreover, reduction of installation and maintenance costs is possible as well as shared infrastructure, logistics and communication facilities and supply lines [64] along with a potential increase in the labor and capital related productivity 
as a result of this complementarity [7,64]. Zaucha [7] also argues that multi-use can motivate clustering of maritime activities and this seems a natural but also promising effect to support social capital related cohesion on land and sea. A comprehensive analysis for defining multi-use MSP is made by Taijjard and Van Niekerk [34] who view multi-use MSP as based on six different key paradigms mostly inspired by the integrated environmental management: The "spatial planning" paradigm, which is the most obvious and prominent; the "objectives-based management" paradigm; the "ecosystem-based approach" paradigm, which is the underpinning principle of MSP in general; the "adaptive management" paradigm which is, as already mentioned, reaffirmed by Christie et al. [33] and of course the "participatory rational decision-making" and the "cooperative environmental governance" ones. It is thus obvious that there are mixed "spatial planning" and "management/governance" related paradigms behind the MU MSP.

\subsection{Multi-Use MSP in Practice}

In the examined literature, some prerequisites to implement MU MSP are reported. Stelzenmüller et al. [19] using the German Exclusive Economic Zone (EEZ) as a case-study, identified a series of key questions and barriers of both institutional and funding order that hamper the effective implementation of co-location as a key procedure in the MSP process: outlining the legal foundation, implementing a licensing process and safety regulations, delineating minimum technical requirements and looking for financial support to establish the business. The requirement for a cohesive framework of regulations is also the conclusion of a study on "multifunctional co-management" in the German waters of the North Sea that mainly assesses extensive development of offshore aquaculture anchored on wind farms [65]. Another suggestion coming from the MUSES Project considers the harmonization of policy and regulation at a national and sub-national level as a critical issue. Of course, this may vary according to the specific administrative and governance arrangements in each country.

Nevertheless, MU is a management option in MSP and as such there is no need for rigid regulations but rather for flexible and transparent management arrangements in the framework of the MSP national laws and the supranational initiatives and strategies. MU should rather be implemented following existing MSP policies, competent authorities and legal provisions in a manner of open coordination in order to not add complexity and bureaucracy related delays, mainly as far as the licensing is concerned. Of course, this is a matter that requires further research per country.

Generally speaking, despite reservations expressed in the literature mainly about its complexity, co-location is a smart and attractive choice for marine planners and stakeholders seeking to reduce conflicts of different sea uses. Stakeholders seem to be, in principle, agreeable to co-locating activities [31] although each combination of activities requires different solutions and arrangements due to the particular nature of the activities concerned [33], e.g., displacement of traditional fishing is often a matter of concern and has to be tackled through intelligent and innovative cooperative ways.

In such a framework of increased context-specific character of operations, stakeholder consultation is essential to verify the scientific findings and highlight the many points and opinions (see Table 2) that need to be addressed in a planning process. Socio-economic research [19] showed that the socio-economic importance of the spatial assemblage of uses varies within planning margins and limitations and concluded that in order to identify appropriate areas of co-location, an interdisciplinary bottom-up approach should be adopted.

In any case, no author was identified to have objections about the complexity of a multi-use MSP with regard to technological requirements, governance arrangements, financial settings and socio-economic and environmental aspects. Thus, to identify realistic and sustainable solutions and designs for multi-use MSP, there is, first of all, a need for early stakeholder engagement in the process of planning and MU implementation [26] and of participatory design processes involving a range of stakeholders representing the private sector from various marine industries and marine groups, public authorities, researchers and Non-Governmental Organizations (NGOs) $[19,21,22]$. In particular, van den Burg et al. [21] fully presented how the already mentioned MERMAID project evaluated the way 
that participation of stakeholders adds to knowledge generation and mutual learning procedures, thus enabling the design of multi-use platforms. Based on a questionnaire addressed to all stakeholders involved in the participatory workshops, they proved that the participatory design process efficiently boosted the implementation of the multi-use concept.

Table 2. Indicative advantages and disadvantages of co-location reported by the literature, as perceived by stakeholders. Sources: $[22,33]$ and own adjustments by authors.

\begin{tabular}{|c|c|}
\hline \multicolumn{2}{|c|}{ Concerning Co-location of Fishing, Wind Farms and Marine Conservation Areas [33] } \\
\hline Potentials/Advantages & Challenges/Disadvantages \\
\hline $\begin{array}{l}\text { Minimizing social and economic impacts on traditional } \\
\text { activities (fishing). }\end{array}$ & $\begin{array}{l}\text { Possibility of hampering conservation objectives due to heavy } \\
\text { windfarm infrastructure }\end{array}$ \\
\hline $\begin{array}{l}\text { Potential support for windfarm activity to engage with } \\
\text { local fishing. }\end{array}$ & Increased responsibilities and costs for wind farm developers. \\
\hline $\begin{array}{l}\text { Support of conservation objectives through restrictions } \\
\text { on fishing activities within windfarms. }\end{array}$ & $\begin{array}{l}\text { Difficulty in achieving consensus for developments, putting } \\
\text { investment potential at risk. }\end{array}$ \\
\hline $\begin{array}{l}\text { Potential support of marine protected areas } \\
\text { management efforts through routine operations in } \\
\text { co-located windfarms. }\end{array}$ & $\begin{array}{l}\text { Risk of limited access to fishing grounds inside windfarms that } \\
\text { would otherwise be targeted. }\end{array}$ \\
\hline $\begin{array}{l}\text { Potential support of habitat related protection targets } \\
\text { through co-location. }\end{array}$ & $\begin{array}{l}\text { Possible need to compromise on the location of protected areas } \\
\text { with sub-optimal overall results. }\end{array}$ \\
\hline & $\begin{array}{l}\text { Risk of non-compensation of fishermen for lost fishing } \\
\text { opportunities }\end{array}$ \\
\hline \multicolumn{2}{|c|}{ Concerning Co-location of Marine Aquaculture and Offshore Wind Energy [22] } \\
\hline Potentials/Advantages & Challenges/Disadvantages \\
\hline Favorable hydrographic conditions. & Unfavorable harsh environmental conditions. \\
\hline $\begin{array}{l}\text { Reduced environmental impacts compared with } \\
\text { nearshore aquaculture. }\end{array}$ & $\begin{array}{l}\text { Potential impacts on marine environnent (nutrient input, noise } \\
\text { impacts). }\end{array}$ \\
\hline $\begin{array}{l}\text { Opportunities with respect to seasonal models with } \\
\text { alternating species. }\end{array}$ & Interactions between caged fish and wild fish. \\
\hline Additional income for the region. & Conflicting views on favorable uses or non-uses. \\
\hline $\begin{array}{l}\text { Well-developed legal framework for offshore wind } \\
\text { energy—opportunity to adapt marine aquaculture } \\
\text { framework. }\end{array}$ & $\begin{array}{l}\text { High investment cost, not attractive for individual fishermen; } \\
\text { possibly only marginal income effects. }\end{array}$ \\
\hline $\begin{array}{l}\text { Cost reduction potential by co-use of infrastructure } \\
\text { (shared maintenance costs). }\end{array}$ & Limited know-how of aquaculture farming in the country. \\
\hline $\begin{array}{l}\text { Develop technological leadership, pioneering } \\
\text { spirit—open up export markets. }\end{array}$ & $\begin{array}{l}\text { Legal uncertainties, e.g., with respect to property rights, } \\
\text { applicability of laws and regulations in the Exclusive Economic } \\
\text { Zone (EEZ) etc. }\end{array}$ \\
\hline $\begin{array}{l}\text { Development of novel technical solutions for } \\
\text { potential export. }\end{array}$ & $\begin{array}{l}\text { Uncertainty with respect to liability and insurance issues and } \\
\text { legal tenure arrangements. }\end{array}$ \\
\hline $\begin{array}{l}\text { Alternative new cultivation more promising than } \\
\text { traditional one in economic terms. }\end{array}$ & High risk/uncertainty with respect to price developments. \\
\hline $\begin{array}{l}\text { Reduced maintenance and cleaning costs (e.g., sharing } \\
\text { of fixed costs for vessels). }\end{array}$ & $\begin{array}{l}\text { High costs of investment-higher cost in development and } \\
\text { application process. }\end{array}$ \\
\hline $\begin{array}{l}\text { Mutual benefits between operators, e.g., in permit } \\
\text { delivery and acceptance by the public. }\end{array}$ & Very limited range of species due to biological requirements. \\
\hline $\begin{array}{l}\text { Identification of selling points (organic certification, } \\
\text { high quality, local products). }\end{array}$ & Safety concerns for workers. \\
\hline $\begin{array}{l}\text { Opportunities such as bio-engineering, bio-extraction } \\
\text { of products and by-products. }\end{array}$ & Other technological and design related uncertainties. \\
\hline $\begin{array}{l}\text { Other more specific economic return and operation } \\
\text { related potentials. }\end{array}$ & \\
\hline
\end{tabular}


In any case, stakeholders should be informed about the real meaning of conflicts [62] and of the possible forms of coordination as well. For example, in MSP, the zoning of the sea frequently demanded by certain competitive activities like aquaculture [36] is an example of "negative coordination" [62] since the idea is to bound activities, create frontiers and avoid interference between them [62]. Beyond this kind of rigid coordination there can also be a soft and positive coordination that shall promote mutual understanding and trust between the stakeholders, more ambitious aspirations and the capacity to build on novel solutions together [62]. The MU MSP and MSP in general should follow this positive coordination mentality.

\section{Results}

\subsection{Adaptation of MSP to Multiple Considerations of the Sea}

It is widely acknowledged that there are multiple understandings of the sea. Beyond the classical considerations of the sea, mostly deriving from the EU policies and directives, as an economic space frequently opposed to its quality as a natural space and a space susceptible to environmental degradation $[33,66,67]$ or even a geographic space $[68,69]$ as opposed to the "mare liberum" related reflections [66,68,70], one can consider the sea as a "physically tangible area" [33] which can be subject to rational, realistic and adjusted decisions in planning whilst there is also a perception of the sea as a "relational and constructed space" [34,71].

Moreover, in contrast to the tangible dimension, an imaginary perception underpins the symbolic dimension of the sea where intangible features and assets have a predominant position. This highly social and cultural perception of the sea may contest a purely rational economic growth planning strategy, with high productivity and optimization connotations. It coincides with the so-called "heritage sea" or "mer patrimoniale" in French, a term that was meant to replace the one of "territorial waters" and a pretty new approach to sea perception and consideration, ruled by a spirit of overcoming and going beyond national jurisdictions in the marine space.

Consequently, MSP has to be able to adapt to these multiple considerations and understandings of the sea, fluctuating from simply being a process for allocating the different marine uses, avoiding conflicts and creating synergies, to a more creative, socially and culturally sensitive process aiming to build attractive identities of sea spaces [72] and high quality landscapes and seascapes, including cultural ones $[66,73,74]$. Of course, attractiveness of marine regions can support well-being and employment opportunities.

In this context, some fundamental questions need to be answered:

- Are the seas and especially the peopled seas susceptible to a cohesive MSP? What is the role of MU MSP in the context of a "maritime cohesion" narrative?

- Is the legally-oriented definition of MU space focusing on resource rights-either exclusive or under inclusive sharing by multiple users, as defined by the MUSES project-sufficient to describe the role of MU in MSP?

- Does MU lead to a rational and optimization-oriented MSP, aiming at creating "islands of high productivity" [7] that might increase the cumulative pressures on marine ecosystems? If so, it might be an unacceptable process since it is widely observed that intense blue growth may produce deep and often unrecoverable changes in the seas. The cumulative impacts of economic activities on marine ecosystems and their performance should be taken seriously into account in planning.

- Are the MU marine spaces or the MU platforms "points of intense concentration of Blue Growth" mostly and basically contributing to the appearance of economies of scale at sea or even of "network agglomeration economies at sea and on land" as Zaucha [7] supports?

- Are they, instead, able to become the "spearhead" for providing balance between economic, social and probably cultural aspirations of planning and mutualistic effects between efficiency, quality and identity related on-site differentiations in the marine space? 
Here it is essential to study the opinions of the different authors or stakeholders concerning multi-use MSP from this "nexus" point of view. Taljaard and van Niekerk [34] support that "multi-use" is an MSP related concept that expresses the evolution from a conservation planning oriented MSP to an MSP that balances economic, social and environmental dimensions of development with a particularly strong commitment to conservation targets. They link MU MSP with the achievement of economic, social and environmental objectives. Another consideration by Michler-Cieluch et al. [3] is that MU MSP is coherent with the EU Integrated Maritime Policy. They express doubts about the possibility for the diverse and often overlapping maritime activities to continue to develop and be managed in an exclusive and independent way. They conclude that an integrated analysis of maritime activities is required, which goes hand-in-hand with the underpinning principle of the EU Integrated Maritime Policy (IMP). It is well known that the IMP and blue growth thinking have their roots in the idea that maritime economic activities cannot be sufficiently developed through a sectoral approach but rather through a holistic management of complex marine social-ecological systems [75].

Therefore, a general recommendation might be that the "multi-use concept" and its various forms of implementation in the various geographical contexts, acts as "spearhead" to reconcile the rational allocation MSP process with a sensitive and creative social and cultural one aiming at building attractive identities of marine spaces. In other words, MU MSP may be a field of balance between "maritime spatial efficiency" and frugality of sea space, "maritime spatial quality" and "maritime spatial identity". In the following sections, a further analysis of this position is approached and an initial conceptualization of "maritime cohesion" between economic efficiency and social and spatial equity, is developed.

\subsection{A Conceptual Framework of Maritime Cohesion}

In the literature, there has never been clear reference to a "maritime cohesion" [36] as an analogue of its territorial counterpart namely "territorial cohesion". "Integration" of policies and sectors or of stakeholders and knowledge or between different national MSP processes is the prevailing term, as already mentioned.

Zaucha [7], in an inspiring book chapter about the applicability of the location theory in marine planning, argues that due to a series of reasons, including its property status, marine space requires collective governance mechanisms that are the so-called "public choice mechanisms" in economics that are usually coupled with administrative resolutions. Despite this, the author believes that "territorial cohesion, frequently applied in relation to terrestrial spatial development appears to be of lesser importance at sea due to the limited presence of human beings there...". He also suggests shortages in the meaning and the content of a goal of territorial cohesion for the sea. He argues that a territorial cohesion goal, together with other goals such as "quality of life" or "spatial integration" should not be treated separately but instead as subsets of broader development paradigms, namely sustainable development or resilience.

But, is that so? Sangiuliano [29] posits that due to the increase of world population, the associated economic activity is overflowing into the marine environment. Therefore, the limited presence of human beings at sea does not make sense whilst their economic activities are very present in the marine environment and in the broader maritime geographical context which influences quality of life. For example, increasing attention should be paid to the integration of MU in MSP to tackle competing sectorial claims and maximize spatial efficiency of seas. Such an ambition leads undoubtedly to the following question: Is it not useful and possible to develop a territorial cohesion thinking and consequently a kind of "maritime cohesion" paradigm for the sea space, at least on particular scales such as some marine geographical spaces that are crowded and peopled and endowed with particular socio-ecological and cultural features (e.g., landscape related tangible and intangible cultural values) such as some insular archipelagos?

If so, should this "maritime cohesion" be viewed as a subset of sustainable development or resilience of the marine social-ecological systems, or as a distinct principle and a goal per se to be 
integrated in maritime spatial plans, involving both efficiency, conservation and social and spatial equity aspirations $[49,51]$ ?

To proceed with this analysis, we should briefly go back to the roots of the "territorial cohesion" concept and thinking [6,41-48] and adapt it, as far as possible, to the peculiarities of the marine environment. Territorial cohesion is mostly about economic efficiency and territorial equity and the thinking behind territorial cohesion can be found in Rawls [41] that extends the principle of equity to sustainable development as the optimum balance between the economy (efficiency), the society (intra-generational equity) and the preservation of the environment (intergenerational equity). If this principle of equity of sustainable development is applied in the marine space and the exploitation of marine resources, the question for maritime cohesion as a planning principle and political goal is the appropriate scale (e.g., local, national, spatially managed area (SMA), sea-basin or pan-European scale etc.) and what framework of multilevel marine governance will govern the relationship between the different levels [76]. It is also of major interest to make reference to Hall [45] who argues that territorial cohesion is substantially the projection of a social philosophy according to which the State has the right and the obligation to intervene in order to adjust the social, economic and territorial inequities caused by the operation of the market. Faludi [46], in his turn, argues that the political idea that introduced the concept of territorial cohesion consists in State support for the provision of services even in areas where such services are considered unprofitable from the market's point of view.

Making the transposition of this idea to the marine realm, there are also lessons to be learnt from the BaltSeaPlan Vision 2030 "Towards the sustainable planning of Baltic Sea space" as well as from the other projects already mentioned in the Materials and Methods Section. Inspired by all the above projects and taking into account territorial cohesion content, philosophy, principles and political implications $[6,44,47]$, a first conceptualization of the "marine/maritime cohesion" is illustrated in the following Figure 1 and Table 3.

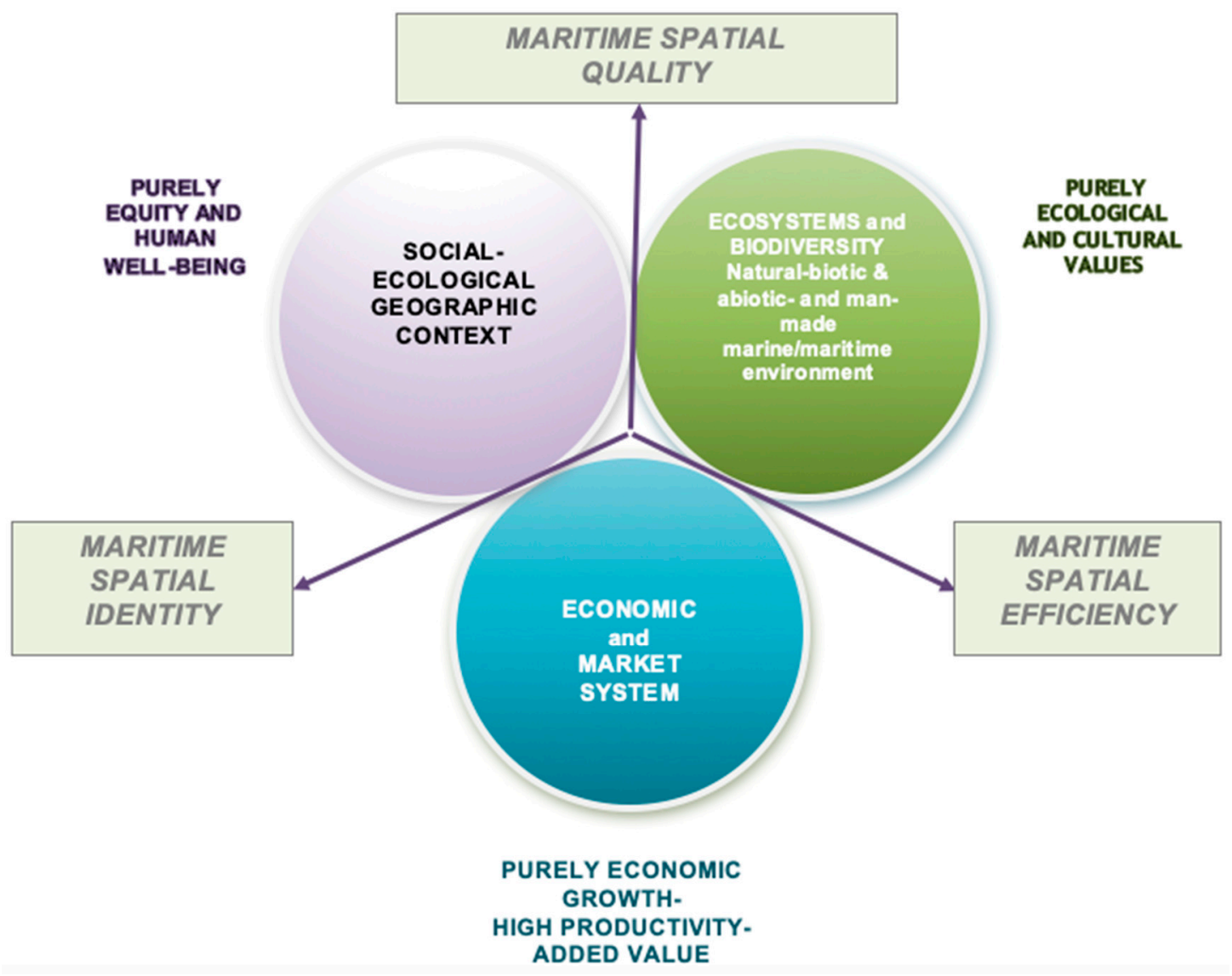

Figure 1. Conceptualization of marine/maritime cohesion. Source: Own elaboration by authors. 
Table 3. Components and sub-components of marine/maritime cohesion.

\begin{tabular}{cc}
\hline Components & Sub-Components (Indicative) \\
\hline 1. Multifunctional use of space \\
2. Co-use and co-management of activities \\
3. Intensity (versus density) linked to multiple-use \\
4. Frugal use of sea space \\
5. High productivity/Economic growth \\
6. Resource efficiency \\
7. Internal connectivity \\
8. External accessibility \\
9. Attractiveness of marine space \\
10. Stimulation of local businesses and complementary income \\
11. Maritime clusters \\
12. Network agglomeration economies on land and sea \\
13. Avoided costs linked with displacement of cultural and \\
provisioning services by co-located uses
\end{tabular}

14. Minimize environmental impacts

15. Creative and smart solutions

16. Shared understanding

17. Creating synergies

18. Mutual learning between marine sectors, participatory knowledge

Marine/Maritime Spatial Quality **

Marine/Maritime Spatial Identity ***
19. Informed stakeholders' engagement

20. High quality seascapes

21. Ethical issues, food security, energy supply

22. Social and spatial equity

23. Distribution of the surplus from coexistence/cooperation among players

24. Adaptive management

25. Green infrastructure and blue corridors in marine areas

26. Aesthetic and recreational resources

27. Landscape resources

28. Tangible and intangible cultural heritage

29. Culturally significant areas-Cultural landscapes and seascapes

30. Local coastal/insular communities

31. Underwater and Marine Cultural heritage (UCH, MCH)

Source: Authors' own elaboration and [35]. * Maritime Spatial Efficiency: Exploitation of local/regional "maritime capital" [68]. Marine resource efficiency along the water column; competitiveness and attractiveness of the marine geographic space; internal connectivity and external accessibility of marine areas. ** Maritime Spatial Quality: Balance of growth targets with conservation and social equity objectives. Quality of the social-ecological system; equity in accessing facilities and services, quality seascapes, creative and smart co-location solutions incl. innovation; adaptive management; ecosystem-based management. ${ }^{* * *}$ Maritime Spatial Identity: Conservation of local/regional "maritime capital" [68]; landscape and cultural heritage; capacity of developing shared visions of the future; creativity; competitive advantage (maritime capital) of each marine area; culturally significant areas, underwater cultural heritage $(\mathrm{UCH})$ and maritime cultural heritage $(\mathrm{MCH})$ prioritized in MSP.

It is of paramount importance to integrate "maritime cohesion" thinking in MS plans, especially for highly sensitive-environmentally, socially and culturally-crowded and peopled marine areas, especially when they present a geographical and historical continuity and thus high symbolic, tangible and intangible values. Obviously, sea-basin cooperation initiatives and macro-regional strategies (e.g., the European Strategy for the Adriatic-Ionian Region, EUSAIR) can also be the subject of a cohesion-oriented discussion between academia and policy makers, as it is already manifest in the various Baltic and Pan-European projects (Section 2.1). In addition, there are key actions in these initiatives and strategies that promote the multi-purpose use of the sea space through combination of two or multiple maritime activities [25]. The co-use is also considered in the Integrated Maritime Plan for the North Sea 2015 describing co-existence of aquaculture with wind energy parks, as a potentially smart use of space, providing opportunities for clever entrepreneurship. 


\subsection{A Definition for MU MSP in the Framework of "Maritime Cohesion"}

As already mentioned, there is no acknowledged definition of "multi-use" MSP on a global level and the MUSES definition, besides focusing on MUS, does not cover the broad MSP scope and should be enriched in order to fully reflect the integrality of the planning and management related paradigms underpinning multi-use MSP.

In other words, it would be important in order to more easily integrate the multi-use concept in MSP, to give a broad definition of MU MSP as a "complex, multidimensional and context-specific process of marine management between multiple users, driven by technological, financial, socio-economic, cultural, environmental and governance related factors - that should be fed by both planning, engineering, governance and management disciplines - so as to achieve an integrated, adaptive, transparent, coordinated, innovative and coherent spatial planning process with limited exclusive rights, in the sea and the oceans".

What really matters, however, is not the accurate definition but instead the successful adaptation of the "multi-use concept" to different territorial and marine contexts. As Papageorgiou and Kyvelou [77] state for MSP in general, the time has come to pave the way for tailor-made practical implementation of MSP. Furthermore, governance and management methods and arrangements in the marine space should be context-specific, taking into account "evolutionary resilience" [11] of marine/coastal social-ecological systems, and since MU MSP is strongly a matter of governance between a wide spectrum of stakeholders, "evolutionary governance" theory and perspectives [78,79]. Marine and coastal areas and their interfaces represent dynamic and complex socio-ecological systems. According to Davoudi [11] such socio-ecological systems are "organized assemblages of humans and non-human life forms" made of bio-geo-physical and social systems with the latter involving complex interrelationships of economic, cultural, institutional and political order. They have developed due to natural processes in continuous interaction with social and economic pressures and are major sources of natural capital and biodiversity. They also provide a series of ecosystem services including cultural ones (CES), thus being sources of inspiration, cultural and recreational values that are important for human well-being and quality of life [11].

As developments in the marine space continuously evolve, maximizing spatial efficiency and minimizing conflicts and negative impacts on the social-ecological systems and on the marine ecosystems should be seen as a dynamic integrated process where innovation can also have a prominent role to play in inventing smart co-existence solutions [4].

\subsection{Measuring "Maritime Cohesion": Is It Possible?}

It is of vital importance not to remain on the "maritime cohesion" conceptual framework but try to make the idea more operational and the "maritime cohesion" measurable in a given marine area [48]. To this end, an indicative set of assessment indicators follows (Table 4), covering the three dimensions of efficiency, quality and identity as formed to be able to adapt to the marine realm. Of course, this set of indicators must be further developed and tested in concrete case-studies. 
Table 4. Indicators to quantify/measure marine/maritime cohesion.

\begin{tabular}{|c|c|c|c|c|}
\hline Components & Sub-Components (Indicative) & & Selected Indicators & Related Sustainable Development Goal (SDG) 14 Indicator \\
\hline \multirow{6}{*}{ Maritime Spatial Efficiency } & Multifunctional use of space & O & $\begin{array}{l}\text { Number of different blue economy related land/sea } \\
\text { uses per ha of coastal area/settlement/municipality } \\
\text { Number of enterprises by BG economic activity or } \\
\text { by sector } \\
\text { Employment by BG economic activity or by sector }\end{array}$ & \\
\hline & Co-use and co-management of activities & O & $\begin{array}{l}\text { Number of enterprises with more than two different } \\
\text { BG secondary economic activities. }\end{array}$ & \\
\hline & $\begin{array}{l}\text { Intensity (versus density) linked to } \\
\text { multiple-use }\end{array}$ & $\begin{array}{l}\circ \\
\circ\end{array}$ & $\begin{array}{l}\text { Number of different sea uses in water column } \\
\text { Capacity/Productivity of different sea uses in } \\
\text { water column }\end{array}$ & \\
\hline & High productivity—Economic growth & $\begin{array}{l}\circ \\
\circ \\
\circ\end{array}$ & $\begin{array}{l}\text { GDP per capita-Evolution in GDP per capita } \\
\text { Sustainable fisheries as a percentage (\%) of GDP } \\
\text { Employment and Unemployment Rates }\end{array}$ & $\begin{array}{l}\text { 14.4.1 } \\
\text { Proportion of fish stocks within biologically sustainable levels } \\
\text { 14.6.1 } \\
\text { Progress by countries in the degree of implementation of } \\
\text { international instruments aiming to combat illegal, unreported and } \\
\text { unregulated fishing } \\
\text { 14.7.1 } \\
\text { Sustainable fisheries as a percentage of GDP in small island } \\
\text { developing States, least developed countries and all countries }\end{array}$ \\
\hline & $\begin{array}{l}\text { Resource efficiency- } \\
\text { Frugal use of sea space }\end{array}$ & $\begin{array}{l}0 \\
0 \\
0 \\
0 \\
0 \\
0\end{array}$ & $\begin{array}{l}\text { Share of regional added value per sector } \\
\text { Labor market efficiency (GDP per working hour) } \\
\text { Accommodation occupancy } \\
\text { Energy efficiency } \\
\text { Telecommunication infrastructure } \\
\text { Business sophistication: employment in the "financial } \\
\text { and insurance activities; real estate activities; } \\
\text { professional, scientific and technical activities; } \\
\text { administrative activities" sectors as percentage (\%) of } \\
\text { total employment }\end{array}$ & \\
\hline & Internal connectivity & $\begin{array}{l}\circ \\
\circ \\
\circ\end{array}$ & $\begin{array}{l}\text { Time connectivity: } \\
\text { Age of settlement in the coastal area } \\
\text { Number of historical periods linked to the settlement } \\
\text { in the coastal area. } \\
\text { Space connectivity: } \\
\text { Number of links of the coastal or sea area to thematic } \\
\text { tourism routes (e.g., sea tourism routes, religious } \\
\text { routes, historical routes, industrial routes, gastronomy } \\
\text { routes, wine routes, etc.) }\end{array}$ & \\
\hline
\end{tabular}


Table 4. Cont.

\begin{tabular}{|c|c|c|c|}
\hline \multirow[t]{24}{*}{ Components } & \multirow{7}{*}{$\begin{array}{l}\text { Sub-Components (Indicative) } \\
\text { External accessibility }\end{array}$} & Selected Indicators & \multirow[t]{7}{*}{ Related Sustainable Development Goal (SDG) 14 Indicator } \\
\hline & & $\begin{array}{l}\text { Accessibility to public maritime/terrestrial } \\
\text { transport/combined-intermodal transport }\end{array}$ & \\
\hline & & $\begin{array}{l}\text { Population living in surrounding regions weighted by } \\
\text { travel time along motorways }\end{array}$ & \\
\hline & & $\begin{array}{l}\text { Population living in surrounding regions weighted by } \\
\text { travel time along railways-daily number of } \\
\text { train passengers }\end{array}$ & \\
\hline & & $\begin{array}{l}\text { Daily number of passenger flights (accessible within } \\
90 \text { min drive) }\end{array}$ & \\
\hline & & Daily number of ferry/boat itineraries & \\
\hline & & $\begin{array}{l}\text { Capacity of marinas expressed by the number of } \\
\text { berths for recreational boating }\end{array}$ & \\
\hline & Building attractiveness of marine space & Number of tourist arrivals & \\
\hline & & Number of tourist nights per number of inhabitants & \\
\hline & & Number of cruise ships arrivals, per month & \\
\hline & & Number of cruise shipping passengers. & \\
\hline & & $\begin{array}{l}\text { Number of accommodation units per municipality } \\
\text { or settlement }\end{array}$ & \\
\hline & & Number of visitors by diving center & \\
\hline & & $\bigcirc \quad$ Foreign direct investments & \\
\hline & Stimulation of local businesses and & Number of local enterprises in BG sectors & \\
\hline & complementary income & $\begin{array}{l}\text { Percentage of complementary income derived from } \\
\text { different BG sectors. }\end{array}$ & \\
\hline & Maritime clusters & Number of maritime clusters & \\
\hline & & Maritime cluster sectors-maritime cluster employees & \\
\hline & & Maritime cluster employee growth & \\
\hline & & Maritime cluster employees per firm & \\
\hline & & Maritime cluster specialization & \\
\hline & & Maritime cluster's environmental focus & \\
\hline & & Maritime cluster share in GDP & \\
\hline & & Maritime cluster fleet (in number of vessels) & \\
\hline
\end{tabular}


Table 4. Cont.

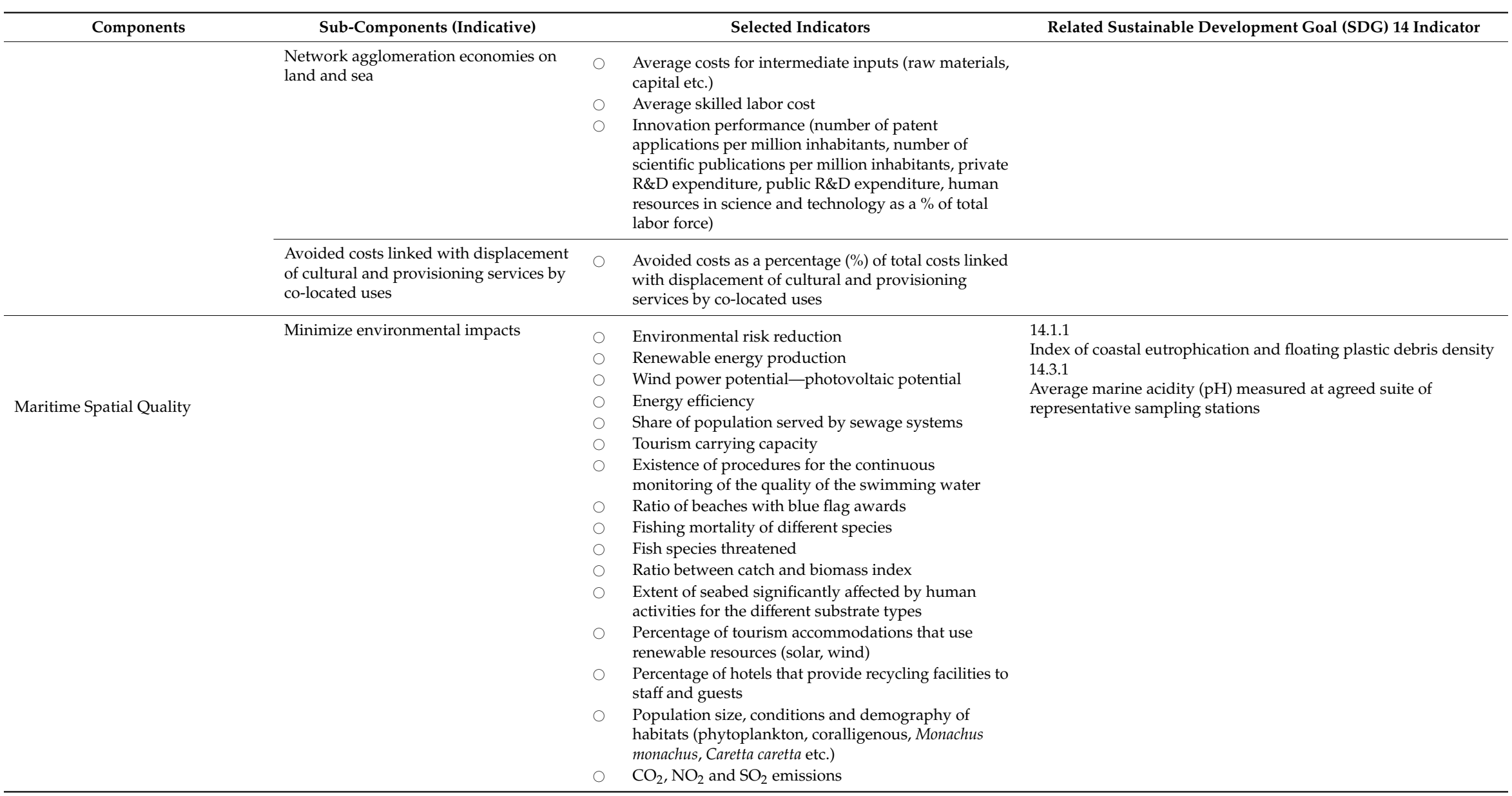


Table 4. Cont.

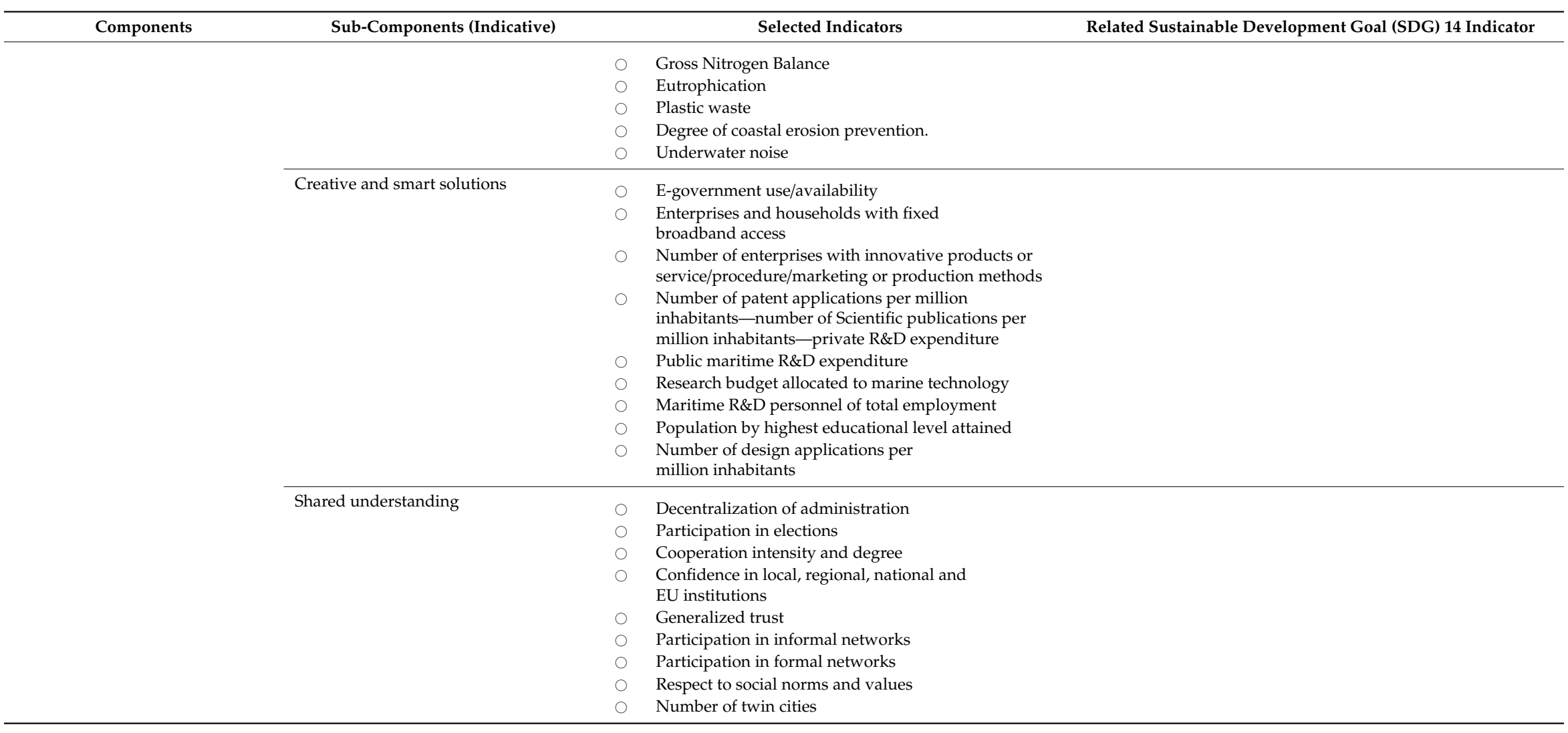


Table 4. Cont.

\begin{tabular}{|c|c|c|c|}
\hline \multirow[t]{24}{*}{ Components } & \multirow{5}{*}{$\begin{array}{l}\text { Sub-Components (Indicative) } \\
\text { Creating synergies }\end{array}$} & Selected Indicators & \multirow[t]{5}{*}{ Related Sustainable Development Goal (SDG) 14 Indicato } \\
\hline & & Number of business networks & \\
\hline & & Number of maritime clusters & \\
\hline & & $\begin{array}{l}\text { Number of enterprises that participate in } \\
\text { business networks }\end{array}$ & \\
\hline & & $\begin{array}{l}\text { Number of enterprises that participate in } \\
\text { maritime clusters }\end{array}$ & \\
\hline & $\begin{array}{l}\text { Mutual learning between marine sectors, } \\
\text { participatory knowledge }\end{array}$ & $\begin{array}{l}\text { Number of employees with knowledge and skills in } \\
\text { BG sectors different from the basic sector } \\
\text { of employment }\end{array}$ & \\
\hline & & Inter-sectoral business networks & \\
\hline & & Inter-sectoral maritime clusters & \\
\hline & Informed stakeholders' engagement & Inter-municipal cooperation & \\
\hline & & Number of regional-local cooperation associations & \\
\hline & & Decentralization of administration & \\
\hline & & Number of twin cities & \\
\hline & & Number of local corporate schemes & \\
\hline & High quality seascapes & Number of underwater antiquities & \\
\hline & & Age of underwater antiquities & \\
\hline & & $\begin{array}{l}\text { Existence of procedures for the continuous } \\
\text { monitoring of the quality of the swimming water }\end{array}$ & \\
\hline & & Ratio of beaches with blue flag awards & \\
\hline & & Fishing mortality of different species & \\
\hline & & Ratio between catch and biomass index & \\
\hline & & $\begin{array}{l}\text { Population size, conditions and demography of } \\
\text { habitats (phytoplankton, coralligenous, Monachus } \\
\text { monachus, Caretta caretta etc.) }\end{array}$ & \\
\hline & & $\mathrm{CO}_{2}, \mathrm{NO}_{2}$ and $\mathrm{SO}_{2}$ emissions & \\
\hline & & Gross Nitrogen Balance & \\
\hline & & Plastic waste recovery rate & \\
\hline & & Fish species threatened & \\
\hline
\end{tabular}


Table 4. Cont.

\begin{tabular}{|c|c|c|c|c|}
\hline \multirow[t]{3}{*}{ Components } & \multirow{2}{*}{$\begin{array}{c}\text { Sub-Components (Indicative) } \\
\text { Social and spatial equity_-Well-being }\end{array}$} & \multicolumn{2}{|r|}{ Selected Indicators } & \multirow{2}{*}{$\begin{array}{l}\text { Related Sustainable Development Goal (SDG) } \mathbf{1 4} \text { Indicator } \\
\text { 14.B.1 } \\
\text { Progress by countries in the degree of application of a } \\
\text { legal/regulatory/policy/institutional framework which recognizes } \\
\text { and protects access rights for small-scale fisheries }\end{array}$} \\
\hline & & $\begin{array}{l}0 \\
0 \\
0 \\
0 \\
0 \\
0 \\
0 \\
0\end{array}$ & $\begin{array}{l}\text { Access to services of general interest } \\
\text { Ageing ratio } \\
\text { Economic dependency ratio } \\
\text { Gender imbalances } \\
\text { Early school leavers } \\
\text { Unemployment and employment rate } \\
\text { Share of population at risk of poverty } \\
\text { Young people Not in Education, Employment or } \\
\text { Training (NEETs) } \\
\text { Self-assessed general health status }\end{array}$ & \\
\hline & Adaptive management & 0 & Strategic planning updated frequency & \\
\hline Maritime Spatial Identity & Aesthetic and recreational resources & $\begin{array}{l}\circ \\
0 \\
0 \\
0 \\
0\end{array}$ & $\begin{array}{l}\text { Population density } \\
\text { Number of cultural sites } \\
\text { Number of underwater and maritime antiquities } \\
\text { Number of maritime ecosystems } \\
\text { Share of protected areas in relation to total marine } \\
\text { area (e.g., Natura 2000) } \\
\text { Surface of protected areas (e.g., Natura 2000) in ha } \\
\text { Ratio of beaches with blue flag awards } \\
\text { Ratio between catch and biomass index } \\
\text { Extent of the seabed significantly affected by human } \\
\text { activities for the different substrate types } \\
\text { Population size, conditions and demography of } \\
\text { habitats (phytoplankton, coralligenous, Monachus } \\
\text { monachus, Caretta caretta etc.) } \\
\text { Quantity of extracted material from coastal/marine } \\
\text { environments (algae, sand, salt) } \\
\text { Quantity of extracted material for use in decoration, } \\
\text { fashion, handicrafts, souvenirs, etc. }\end{array}$ & $\begin{array}{l}\text { 14.3.1 } \\
\text { Average marine acidity }(\mathrm{pH}) \text { measured at agreed suite of } \\
\text { representative sampling stations } \\
\text { 14.5.1 } \\
\text { Coverage of protected areas in relation to marine areas }\end{array}$ \\
\hline
\end{tabular}


Table 4. Cont.

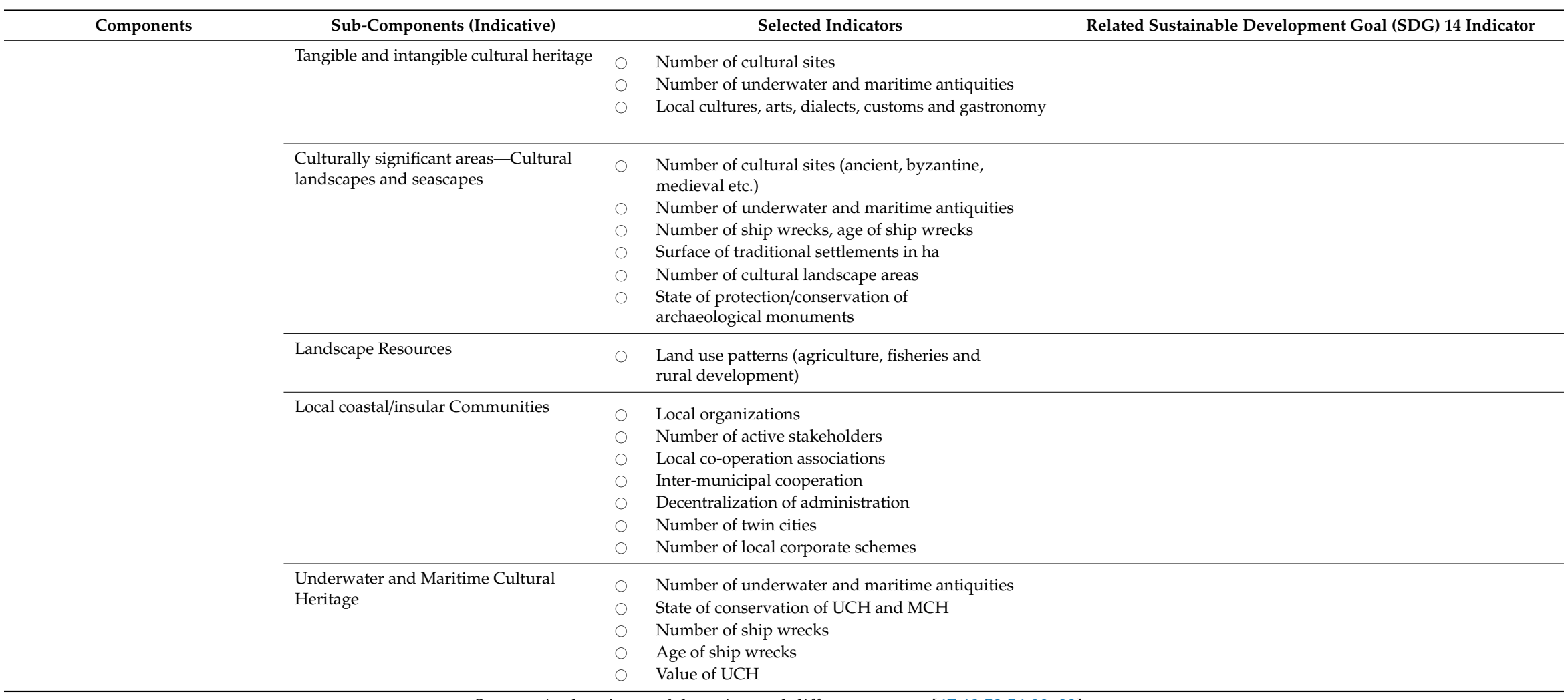

Source: Authors' own elaboration and different sources [47,48,52,54,80-83]. 
Following the above selected indicators, some examples of interconnections between them can be identified, meaning that changes in components of maritime cohesion lead to changes and adaptations to other components of maritime cohesion:

- The minimization of environmental impacts, a sub-component of "Maritime Spatial Quality", measured for example, by the share of population served by sewage systems, the existence of procedures for the continuous monitoring of the quality of the swimming water or the fishing mortality of different species can influence the "Maritime Spatial Efficiency" through the multifunctional use of space (measured for example, by the number of enterprises of Blue economic activity or sector), high productivity (measured by sustainable fisheries as a percentage of GDP), building attractiveness of marine space (measured for example, by the number of tourist arrivals, the number of tourist nights or the number of visitors by diving center) or the stimulation of local businesses and complementary income (measured by the percentage of complementary income derived from different BG sectors).

- The aesthetic and recreational resources, a sub-component of "Maritime Spatial Identity", measured for example, by the surface of protected area (e.g., Natura 2000) in ha, the extend of the seabed significantly affected by human activities for the different substrate types or the population size, conditions and demography of habitats (phytoplankton, coralligenous, Monachus monachus, Caretta caretta etc.) can influence the "Maritime Spatial Quality" through the minimization of environmental impacts (measured for example, by the environmental risk reduction) or the high quality of seascapes (measured for example by the ratio between catch and biomass index or the Gross Nitrogen Balance or the fish species threatened).

- The shared understanding (measured for instance, by the generalized trust, the participation in informal sectors or the participation in formal networks) the creation of synergies (measured for example, by the number of business networks) and the tangible and intangible cultural heritage (measured for example, by local cultures, arts, dialects etc.) sub-components of "Maritime Spatial Quality" can influence the "Maritime Spatial Efficiency" through the creation of Maritime Clusters (measured by the number of maritime clusters, the maritime cluster specialization or the maritime cluster fleet, in number of vessels) and the Network agglomeration economies on land and sea (measured by the average skilled labor cost, the average costs for intermediate inputs, or the innovation performance, etc.).

- The creative and smart solutions, a sub-component of "Maritime Spatial Quality", (measured for example by the number of patent applications per million inhabitants or by the research budget allocated to marine technology) can influence the "Maritime Spatial Efficiency" through the high productivity and economic growth (measured for example, by GDP per capita or the evolution in GDP per capita).

- The shared understanding, a sub-component of "Maritime Spatial Quality", measured for example, by the generalized trust, the participation in informal sectors or the participation in formal networks can influence the "Maritime Spatial Identity" through Local coastal/insular communities (measured by the number of local corporate schemes, the number of local organizations, the number of active stakeholders or the number of inter-municipal cooperation).

\section{Discussion}

This article aimed to develop a conceptual framework for "maritime cohesion" and to explore whether integrating the huge and extensive potential of the "multi-use" management in MSP can stimulate a collaborative, cohesive and assemblage thinking in the process. Since one of the goal of MSP is to sustainably manage marine resources, from a first look, areas where multiple sectors interact present high risk of being overexploited if market-driven high productivity objectives are to be fulfilled. In this case, great care must be taken to keep the spatial allocation within the limits of environmental, social and cultural sustainability. Besides, where multiple sectors manifest conflicting claims for space, 
there is, in principle, potential for negative impacts on long-term economic sustainability, also given that trade-offs are rarely addressed explicitly or transparently [84].

This has to be reversed, by trying to identify win-win options that would additionally favor equity and fair distribution of the excess from coexistence/cooperation among actors, thereby efficiently answering the conflicts [54]. Moreover, conflicts are also observed due to the different views, values and attitudes of people and social groups living in coastal areas and on islands. Consequently, their involvement in the procedure is a sine-qua-non condition. The ongoing or realized maritime spatial plans show that MSP is a highly participatory planning procedure.

Furthermore, in order to develop an appropriate planning and governance framework for co-location of marine activities, several understandings are required of both ecological, geographical, socio-economic and legal, economic viability, operation, technology and design related issues and challenges. Each marine industry has its own consideration for allocation. Thus, on the initiative of the competent authorities that coordinate MSP, channels have to be created between them in order to achieve high productivity without compromising social, environmental and cultural targets as expressed by the different stakeholders and the local communities. The sustained growth of marine industries must be fostered through forms of MSP and marine governance that fully acknowledge the potential of multi-use combinations for the sea-basin or the particular region concerned.

Finally, in order to address contemporary challenges in marine areas, MSP needs to work on communication processes that link different types of information and promote the dialogue and shared understanding between social groups and spatial scales especially in times of complexity and uncertainty. In other words, connected forward-thinking in MSP should not ignore "maritime cohesion" as a counterpart of the so much discussed territorial cohesion, especially as far as planning through different scales of the marine space, is concerned.

Besides, like the trend in contemporary territorial development to cross and overcome jurisdictional boundaries and physical frontiers [85] incited by the evolution of information and communication technologies, a movement further offshore, towards deeper waters might be anticipated for most marine industries, resulting in more opportunities for industry co-locations and minimized potential competing claims for space. This, in turn, may induce ownership and rights related questions, and also new sharing of competencies particularly when activities take place in the areas beyond national jurisdictions (ABNJ).

\section{Conclusions and Key Recommendations}

A general conclusion is that intersecting marine operational boundaries does not only generate eventual conflicts but can also pave the way towards potential cooperation, complementarities with consecutive added value, joint public and private benefits [63], surplus distribution effects and finally a cohesive co-existence perspective.

To this end, a first recommendation of this research is that a cohesive thinking should explicitly be initiated in MSP national regulations and macro-regional strategies. Like the "territorial cohesion" concept initially conceived as a means of ensuring public choice mechanisms where there are market failures, a "maritime cohesion" thinking is necessary and should be addressed as a priority in marine areas and insular territories that are crowded and peopled and endowed with particular geographic and cultural features, to enhance public choice mechanisms. Such an initial conceptual framework is introduced, discussed and analyzed in the Results Section.

A second recommendation is that a set of assessment indicators should follow the conceptual framework, to make the idea more operational. Of course, this set of indicators must be further developed, probably enriched, and their validity tested through concrete case-studies.

A strategic and forward-thinking MSP may encourage integrated and less sectoral thinking in a comprehensible way, both within national borders and beyond them [30]. Poly-criterial methodologies (see Table 3) based on the concept of "maritime cohesion" are necessary to inform strategic MSP thinking and to provide data and ex-ante impact assessment indicators (Table 4). Conflict and opportunity 
matrixes already developed can be of assistance mainly for facilitating discussion with regard to scenarios of a cohesive multi-use MSP.

The forthcoming United Nations Decade of Ocean Science for Sustainable Development (2021-2030) provides an excellent opportunity for both academia and policy makers to build on "maritime cohesion", combining economic, social, ecological and cultural aspirations of societies. In order to achieve ocean sustainability, we should take into account all three pillars (i.e., ecological, economic and social) and also the developments through which ocean sustainability is pursued [21]. In this sense, the development of integrated, sensitive and adaptive management approaches and new planning and financial tools to serve external (between marine areas) and internal (in the same marine area) "maritime cohesion" is of paramount importance.

For the widely-acknowledged MSP to become an efficient tool for coordinating multiple uses and sectorial interests in the sea, it is important to encompass a "maritime cohesion" concept in institutional settings and in practice through an impact assessment methodology (Table 3). "Maritime cohesion" can be more easily translated in practice compared with broader sustainable development targets that can be too numerous when specified and often incompatible [53], or with environmental justice implications that are certainly useful but probably more difficult to implement [86].

Maritime cohesion is certainly of particular importance for sea-basins like the Mediterranean with significant potential for multiple use of marine space, particularly in crowded and peopled marine areas, for example, the Hellenic poly-insular region of the Aegean Archipelago which is a heterogeneous space that despite its blue growth potential, also presents several social vulnerabilities mainly deriving from the unaffordability of the transportation costs of persons and goods that increase the total living cost in the islands and hamper their attractiveness in terms of tourism [50]. However, these perceptions are often quite immature on national levels, despite the use of the "territorial cohesion" term in political discourses, for example for the implementation of the "Road Equivalent Tariff" for the Aegean islands [87], and are also hampered by political and geopolitical struggles.

Thus, another recommendation of this research is that states and regions sharing the common sea should be encouraged to undertake studies at macro-regional (e.g., EUSAIR), national and regional levels to define multi-use potentialities, as a step towards updating MSP strategies and refining planning towards a regionally specific, operational blue growth strategy [75].

The defenders of collaborative communicative planning [88,89] claim that planning is an interdisciplinary field of cooperation, based on interaction, authentic dialogue, communication and consultation among various groups with different interests in planning priorities. In this sense, integrated and cohesive multi-use MSP is also an excellent field of work for spatial planners. Nevertheless, planners, both scientists and practitioners, need to be sufficiently familiar with adaptive management techniques since there is no "one-size-fits-all" management approach [90] and also with the large spectrum of spatial tools developed so far, focusing, however on the biophysical environment. It is obvious that maritime spatial analysis tools should address the complexity of a cohesive, interdisciplinary and place-based MSP procedure [91] on the basis of the framework discussed in this paper.

Author Contributions: The authors contributed equally to this work.

Funding: This research received no external funding.

Acknowledgments: The authors would like to warmly thank the anonymous reviewers for their precious comments and recommendations to improve the content and form of this paper.

Conflicts of Interest: The authors declare no conflict of interest.

\section{References}

1. United Nations. Sustainable Development Goals, SDG 14. 2018. Available online: http:// sustainabledevelopment.un.org/sdg14 (accessed on 29 April 2019). 
2. Doumbia-Henry, C. Maritime, Oceans and Sustainability-A Way Forward. WMU J. Marit. Aff. 2016, 15, 1-4. [CrossRef]

3. Michler-Cieluch, T.; Krause, G.; Buck, B.H. Reflections on integrating operation and maintenance activities of offshore wind farms and mariculture. Ocean Coast. Manag. 2009, 52, 57-68. [CrossRef]

4. Kyriazi, Z.; Maes, F.; Degraer, S. Coexistence dilemmas in European marine spatial planning practices. The case of marine renewables and marine protected areas. Energy Policy 2016. [CrossRef]

5. Ehler, C.; Zaucha, J.; Gee, K. Maritime/Marine Spatial Planning at the Interface of Research and Practice. In Marine Spatial Planning; Zaucha, J., Gee, K., Eds.; Palgrave Macmillan: Basingstoke, UK, 2019.

6. Kyvelou, S. (Ed.) From Spatial Planning to Territorial Management: The Notions of Strategic Spatial Planning and Territorial Cohesion in Europe; KRITIKI: Athens, Greece, 2010; p. 344. (In Greek)

7. Zaucha, J. Can Classical Location Theory Apply to the Sea Space? In Maritime Spatial Planning; Zaucha, J., Gee, K., Eds.; Palgrave Macmillan: Basingstoke, UK, 2019.

8. Gee, K.; Kannen, A.; Heinrichs, B. BaltSeaPlan Vision 2030 for Baltic Sea Space. Hamburg, Germany, Autumn 2011. Available online: www.baltseaplan.eu/index.php/BaltSeaPlanVision-2030;494/1 (accessed on 29 April 2019).

9. Lacroix, D.; Pioch, S. The multi-use in wind farm projects: More conflicts or a win-win opportunity? Aquat. Living Resour. 2011, 24, 129-135. [CrossRef]

10. Winder, G.M.; Le Heron, R. Assembling a Blue Economy moment? Geographic engagement with globalizing biological-economic relations in multi-use marine environments. Dialogues Hum. Geogr. 2017, 7, 3-26. [CrossRef]

11. Davoudi, S.; Zaucha, J.; Brooks, E. Evolutionary resilience and complex lagoon systems. Integr. Environ. Assess. Manag. 2016, 12, 711-718. [CrossRef]

12. Bennett, N.J. Marine Social Science for the Peopled Seas. Coast. Manag. 2019. [CrossRef]

13. Mazor, T.; Possingham, H.P.; Edelist, D.; Brokovich, E.; Kark, S. The Crowded Sea: Incorporating Multiple Marine Activities in Conservation Plans Can Significantly Alter Spatial Priorities. PLoS ONE 2014, 9, e104489. [CrossRef]

14. Klinger, D.H.; Eikeset, A.M.; Davíðsdóttir, B.; Winter, A.M.; Watson, J.R. The mechanics of blue growth: Management of oceanic natural resource use with multiple, interacting sectors. Mar. Policy 2018, 87, 356-362. [CrossRef]

15. Dalton, G.; Bardócz, T.; Blanch, M.; Campbell, D.; Johnson, K.; Lawrence, G.; Lilas, T.; Friis-Madsen, E.; Neumann, F.; Nikitas, N.; et al. Feasibility of investment in Blue Growth multiple-use of space and multi-use platform projects; results of a novel assessment approach and case studies. Renew. Sustain. Energy Rev. 2019, 107, 338-359. [CrossRef]

16. Röckmann, C.; Lagerveld, S.; Stavenuiter, J. Operation and Maintenance Costs of Offshore Wind Farms and Potential Multi-use Platforms in the Dutch North Sea. In Aquaculture Perspective of Multi-Use Sites in the Open Ocean; Buck, B., Langan, R., Eds.; Springer: Cham, Germany, 2017; pp. 97-113. [CrossRef]

17. Elginoz, N.; Bas, B. Life Cycle Assessment of a multi-use offshore platform: Combining wind and wave energy production. Ocean Eng. 2017, 145, 430-443. [CrossRef]

18. Zanuttigh, B.; Angelelli, E.; Bellotti, G.; Romano, A.; Krontira, Y.; Troianos, D.; Suffredini, R.; Franceschi, G.; Cantù, M.; Airoldi, L.; et al. Boosting Blue Growth in a Mild Sea: Analysis of the Synergies Produced by a Multi-Purpose Offshore Installation in the Northern Adriatic, Italy. Sustainability 2015, 7, 6804-6853. [CrossRef]

19. Stelzenmüller, V.; Diekmann, R.; Bastardie, F.; Schulze, T.; Berkenhagen, J.; Kloppmann, M.; Krause, G.; Pogoda, B.; Buck, B.H.; Kraus, G. Co-location of passive gear fisheries in offshore wind farms in the German EEZ of the North Sea: A first socio-economic scoping. J. Environ. Manag. 2016, 183, 794-805. [CrossRef] [PubMed]

20. Stuiver, M.; Soma, K.; Koundouri, P.; Van den Burg, S.; Gerritsen, A.; Harkamp, T.; Dalsgaard, N.; Zagonari, F.; Guanche, R.; Schouten, J.-J. The Governance of Multi-Use Platforms at Sea for Energy Production and Aquaculture: Challenges for Policy Makers in European Seas. Sustainability 2016, 8, 333. [CrossRef]

21. van den Burg, S.; Stuiver, M.; Norrman, J.; Garção, R.; Söderqvist, T.; Röckmann, C.; Schouten, J.-J.; Petersen, O.; García, R.G.; Diaz-Simal, P. Participatory Design of Multi-Use Platforms at Sea. Sustainability 2016, 8, 127. [CrossRef] 
22. Wever, L.; Krause, G.; Buck, B.H. Lessons from stakeholder dialogues on marine aquaculture in offshore wind farms: Perceived potentials, constraints and research gaps. Mar. Policy 2015, 51, 251-259. [CrossRef]

23. Brennan, F.; Kolios, A. Structural Integrity Considerations for the H2OCEAN Multi Modal Wind-Wave Platform, European Wind Energy Association Conference and Exhibition 2014, EWEA 2014. Available online: https://www.scopus.com/inward/record.uri?eid=2-s2.0-84925584642\&partnerID=40\& md5=8e803bc9c3cbea2114698999ec6ff90e (accessed on 29 April 2019).

24. Mikkola, E.; Heinonen, J.; Kankainen, M.; Hekkala, T.; Kurkela, J. Multi-Platform Concepts for Combining Offshore Wind Energy and Fish Farming in Freezing Sea Areas: Case Study in the Gulf of Bothnia. In Proceedings of the ASME 2018 37th International Conference on Offshore Mechanics and Arctic Engineering; American Society of Mechanical Engineers: New York, NY, USA, 2018; Volume 6, p. V006T05A029. [CrossRef]

25. Depellegrin, D.; Venier, C.; Kyriazi, Z.; Vassilopoulou, V.; Castellani, C.; Ramieri, E.; Bocci, M.; Fernandez, J.; Barbanti, A. Exploring Multi-Use potentials in the Euro-Mediterranean sea space. Sci. Total Environ. 2019, 653, 612-629. [CrossRef]

26. Calado, H.; Papaioannou, E.A.; Caña-Varona, M.; Onyango, V.; Zaucha, J.; Przedrzymirska, J.; Roberts, T.; Sangiuliano, S.J.; Vergílio, M. Multi-uses in the Eastern Atlantic: Building bridges in maritime space. Ocean Coast. Manag. 2019, 174, 131-143. [CrossRef]

27. Legorburu, I.; Johnson, K.R.; Kerr, S.A. Multi-use maritime platforms-North Sea oil and offshore wind: Opportunity and risk. Ocean Coast. Manag. 2018, 160, 75-85. [CrossRef]

28. Benassai, G.; Mariani, P.; Stenberg, C.; Christoffersen, M. A Sustainability Index of potential co-location of offshore wind farms and open water aquaculture. Ocean Coast. Manag. 2014, 95, 213-218. [CrossRef]

29. Sangiuliano, S.J. Analysing the potentials and effects of multi-use between tidal energy development and environmental protection and monitoring: A case study of the inner sound of the Pentland Firth. Mar. Policy 2018, 96, 120-132. [CrossRef]

30. Buck, B.H.; Krause, G.; Michler-Cieluch, T.; Brenner, M.; Bucholz, C.M.; Busch, J.A.; Fisch, R.; Geisen, M.; Zielinski, O. Meeting the quest for spatial efficiency: Progress and prospects of extensive aquaculture within offshore wind farms. Helgol. Mar. Res. 2008, 62, 269-281. [CrossRef]

31. Jansen, H.M.; Van Den Burg, S.; Bolman, B.; Jak, R.G.; Kamermans, P.; Poelman, M.; Stuiver, M. The feasibility of offshore aquaculture and its potential for multi-use in the North Sea. Aquac. Int. 2016, 24, 735. [CrossRef]

32. Christie, N.; Smyth, K.; Barnes, R.; Elliott, M. Co-location of activities and designations: A means of solving or creating problems in marine spatial planning? Mar. Policy 2014, 43, 254-261. [CrossRef]

33. Kannen, A. Challenges for Marine Spatial Planning In the Context of Multiple Sea Uses, Policy Arenas and Actors Based On Experiences From the German North Sea. Reg. Environ. Chang. 2014, 14, 2139-2150. [CrossRef]

34. Taljaard, S.; van Niekerk, L. How supportive are existing national legal regimes for multi-use marine spatial planning? The South African case. Mar. Policy 2013, 38, 72-79. [CrossRef]

35. Kyvelou, S.; Giannopoulou, E. The multi-use concept in the marine space: Towards a form of maritime cohesion? In Proceedings of the International Conference ECHOPOLIS 2018, Athens, Greece, 10 April 2018. in press.

36. Schupp, M.F.; Bocci, M.; Depellegrin, D.; Kafas, A.; Kyriazi, Z.; Lukic, I.; Schultz-Zehden, A.; Krause, G.; Onyango, V.; Buck, B.H. Toward a Common Understanding of Ocean Multi-Use. Front. Mar. Sci. 2019. [CrossRef]

37. Jentoft, S.; Knol, M. Marine Spatial Planning: Risk or opportunity for fisheries in the North Sea? Marit. Stud. 2014, 12, 13. [CrossRef]

38. Douvere, F.; Ehler, C.N. New perspectives on sea use management: Initial findings from.European experience with marine spatial planning. J. Environ. Manag. 2009, 90, 77-88. [CrossRef]

39. Marine Management Organisation (MMO). Marine Planning and Development. 2014. Available online: https://www.gov.uk/guidance/marine-plans-development (accessed on 29 April 2019).

40. Zanuttigh, B.; Angelelli, E.; Kortenhaus, A.; Koca, K.; Krontira, Y.; Koundouri, P. A methodology for multi-criteria design of multi-use offshore platforms for marine renewable energy harvesting. Renew. Energy 2016, 85, 1271-1289. [CrossRef]

41. Rawls, J. A Theory of Justice; Oxford University Press: Oxford, UK, 1971.

42. Davoudi, S. Understanding Territorial Cohesion. Plan. Pract. Res. 2005, 20, 433-441. [CrossRef] 
43. Davoudi, S. Territorial Cohesion, the European Social Model, and Spatial Policy Research. In Territorial Cohesion and the European Model of Society; Faludi, A., Ed.; Lincoln Institute of Land Policy: Cambridge, MA, USA, 2005; pp. 81-103.

44. Camagni, R. Progress on an ex-ante assessment tool for territorial impact of EU policies: The TEQUILA model and beyond. In Proceedings of the ESPON Seminar, Evora, Portugal, 12-13 November 2007.

45. Hall, P. Fundamental questions for the ESDP. In Town and Country Planning; The Town and Country Planning Association: London, UK, November 2005.

46. Faludi, A. Territorial cohesion: Old (French) Wine in new Bottles? Urban Stud. 2004, 47, 1349-1365. [CrossRef]

47. Prezioso, M. Cohesion policy: Methodology and indicators towards common approach. Rom. J. Reg. Sci. 2008, 2, 1-32.

48. Zaucha, J.; Böhme, K. Measuring Territorial Cohesion is not a Mission Impossible. Eur. Plan. Stud. 2019. [CrossRef]

49. Halpern, B.S.; Klein, C.J.; Brown, C.J.; Beger, M.; Grantham, H.S.; Mangubhai, S.; Ruckelshaus, M.; Tulloch, V.J.; Watts, M.; White, C.; et al. Achieving the triple bottom line in the face of inherent trade-offs among social equity, economic return, and conservation. Proc. Natl. Acad. Sci. USA 2013, 110, 6229-6234. [CrossRef] [PubMed]

50. Papadakis, N.; Kyvelou, S. Greek Islands in Crisis: Social Vulnerability and the Need for Integrated Territorial Development Strategies. Eur. Q. Political Attitudes Ment. 2017, 6, 67-88.

51. Kyriazi, Z.; Lejano, R.; Maes, F.; Degraer, S. A cooperative game-theoretic framework for negotiating marine spatial allocation agreements among heterogeneous players. J. Environ. Manag. 2016, 187, 444-455. [CrossRef]

52. Issaris, Y.; Katsanevakis, S.; Pantazi, M.; Vassilopoulou, V.; Panayotidis, P.; Kavadas, S.; Kokkali, A.; Salomidi, M.; Frantzis, A.; Panou, A. Ecological mapping and data quality assessment for the needs of ecosystem-based marine spatial management: Case study Greek Ionian Sea and the adjacent gulfs. Mediterr. Mar. Sci. 2012, 13, 297-311. [CrossRef]

53. Haëntjens, J. La ville frugale; Presses Universitaires de France (PUF): Paris, France, 2012.

54. BONUS BALTSPACE Project (2015-2018). Available online: https://www.baltspace.eu (accessed on 29 April 2019).

55. Schultz-Zehden, A.; Weig, B.; Lukic, I. Maritime Spatial Planning and the EU's Blue Growth Policy: Past, Present and Future Perspectives. In Maritime Spatial Planning; Zaucha, J., Gee, K., Eds.; Palgrave Macmillan: Basingstoke, UK, 2019.

56. Budzich-Tabor, U.; Burch, M.; Silva, S.G. Farnet Guide \#9: Conjuguer Pêche et Tourisme au Profit des Populations Locales. European Union: Brussels, Belgium, 2014. [CrossRef]

57. Przedrzymirska, J.; Zaucha, J.; Depellgrin, D.; Fairgrieve, R.; Kafas, A.; Calado, H.M.G.P.; de Sousa Vergílio, M.H.; Varona, M.C.; Lazić, M.; Schultz-Zehden, A.; et al. Multi-use of the sea: From research to practice. In SHS Web of Conferences; EDP Sciences: Les Ulis, France, 2018; Volume 58, p. 01025.

58. Space@Sea Project. Available online: https://spaceatsea-project.eu (accessed on 10 June 2019).

59. Blue Growth Farm Project. Available online: http://www.thebluegrowthfarm.eu (accessed on 10 June 2019).

60. ESPON-on-the-Road Project, Demonstration Material Entitled "Blue Growth, the Maritime Reality from a European Perspective" Elaborated by the Greek ESPON Contact Point, Athens. 2014. Available online: http://www.esponontheroad.eu/dane/web_articles_files/2107/gr_blue_growth.pdf (accessed on 29 April 2019).

61. Bennett, N.J. Navigating a just and inclusive path towards sustainable oceans. Mar. Policy 2018, 97, $139-146$. [CrossRef]

62. Arbo, P.; Thủy, P.T.T. Use conflicts in marine ecosystem-based management-The case of oil versus fisheries. Ocean Coast. Manag. 2016, 122, 77-86. [CrossRef]

63. Kite-Powell, H.L. Economics of Multi-use and Co-location. In Aquaculture Perspective of Multi-Use Sites in the Open Ocean; Buck, B., Langan, R., Eds.; Springer: Cham, Germany, 2017. [CrossRef]

64. Gimpel, A.; Stelzenmüller, V.; Töpsch, S.; Galparsoro, I.; Gubbins, M.; Miller, D.; Murillas, A.; Murray, A.G.; Pınarbaşı, K.; Roca, G.; et al. A GIS-based tool for an integrated assessment of spatial planning trade-offs with aquaculture. Sci. Total Environ. 2018, 627, 1644-1655. [CrossRef] [PubMed] 
65. Buck, B.H.; Krause, G.; Michler-Cieluch, T.; Rosenthal, H. Extensive open ocean aquaculture development within wind farm in Germany: The project of offshore co-management and legal constraints. Ocean Coast. Manag. 2004, 47, 95-122. [CrossRef]

66. Gee, K. The Ocean Perspective. In Maritime Spatial Planning; Zaucha, J., Gee, K., Eds.; Palgrave Macmillan: Basingstoke, UK, 2019; pp. 23-45.

67. Kyvelou, S. Maritime spatial planning as evolving policy in Europe: Attitudes, challenges and trends, European Quarterly of Political Attitudes and Mentalities. Q. Political Attitudes Ment. 2017, 6, 1-14.

68. Kyvelou, S. Maritime Spatial Issues: Maritime Dimension of Territorial Cohesion, Maritime Spatial Planning-Sustainable Blue Growth; Kyvelou, S., Ed.; KRITIKI: Athens, Greece, 2016. (In Greek)

69. Trouillet, B. Les enjeux spatiaux: La reconfiguration des espaces halieutiques. In Espaces Maritimes et Territoires Marins; Guillaume, J., Carrefours, C., Wackerman, G., Eds.; Ellipses: New York, NY, USA, 2015; pp. 53-88.

70. Labrot Véronique, L. De l'application de la notion de territoire en mer. Quelques réflexions juridiques inabouties, Colloque. In Proceedings of the L'aménagement du territoire maritime dans le contexte de la politique maritime intégrée, Paris, France, 9-10 October 2014.

71. Jay, S.; Ellis, G.; Kidd, S. Marine Spatial Planning: A New Frontier? J. Environ. Policy Plan. 2012, 14, 1-5. [CrossRef]

72. Kyvelou, S. Report Presented to the Committee of Trade and Production of the Greek Parliament for the Discussion of the Draft Greek Law on Maritime Spatial Planning, Athens. 30 May 2018. Available online: https://www.academia.edu/38340987/EI (accessed on 29 April 2019). (In Greek)

73. Kyvelou, S. Toward quality marine landscape plans. Presented at the 22nd Council of Europe Meeting of the Workshops for the implementation of the European landscape Convention and International Congress "Water, landscape and citizenship in the face of global change", Seville, Spain, 14-16 March 2019.

74. Gee, K. Offshore wind power development as affected by seascape values on the German North Sea coast. Land Use Policy 2010, 27, 185-194. [CrossRef]

75. Kyvelou, S.; Ierapetritis, D. How to make blue growth operational? A local and regional stakeholders perspective in Greece. J. Marit. Aff. 2019. [CrossRef]

76. Van Tatenhove, J. Marine Governance: Institutional Capacity-building in a multi-level Governance Setting. In Governing Europe's Marine Environment; Gilek, M., Kern, K., Eds.; Ashgate: Farnham, UK, 2015.

77. Papageorgiou, M.; Kyvelou, S. Aspects of marine spatial planning and governance: Adapting to the transboundary nature and the special conditions of the sea. Eur. J. Environ. Sci. 2018, 8, 31-37. [CrossRef]

78. Van Assche, K.; Hornidge, A.K.; Schlüter, A.; Vaidianu, N. Governance and the coastal condition: Towards new modes of observation, adaptation and integration. Mar. Policy 2019. [CrossRef]

79. Van Assche, K.; Beunen, R.; Duineveld, M. Evolutional Governance Theory: An Introduction; Springer: Heidelberg, Germany, 2014; Available online: http:/www.springer.com/gp/book/9783319009834 (accessed on 29 April 2019).

80. Böhnke-Henrichs, A.; Baulcomb, C.; Koss, R.; Salman Hussain, S.; de Groot, R.S. Typology and indicators of ecosystem services for marine spatial planning and management. J. Environ. Manag. 2013, 130, 135-145. [CrossRef]

81. Annoni, P.; Dijkstra, L.; Gargano, N. EU Regional Competitiveness Index 2016; Regional and Urban Policy, Working Papers, A Series of Short Papers on Regional Research and Indicators Produced by the Directorate-General for Regional and Urban Policy; European Commission: Brussels, Belgium, 2017.

82. Hollanders, H.; Es-Sadki, N. Regional Innovation Scoreboard 2017; European Union Publication: Luxembourg, 2017; Available online: https://ec.europa.eu/docsroom/documents/31491 (accessed on 29 April 2019).

83. Ierapetritis, D. Social Capital, Regional Development and Innovation in Greece: An Interregional Analysis. Int. J. Innov. Reg. Dev. 2019, in press.

84. van den Burg, S.W.K.; Aguilar-Manjarrez, J.; Jenness, J.; Torrie, M. Assessment of the geographical potential for co-use of marine space, based on operational boundaries for Blue Growth sectors. Mar. Policy 2019, 100, 43-57. [CrossRef]

85. European Observatory for Territorial and Cohesion (ESPON) 2000-2006 and 2007-2013. Available online: www.espon.eu (accessed on 29 April 2019).

86. De Santo, E.M. Environmental justice implications of maritime spatial planning in the European Union. Mar. Policy 2011, 35, 34-38. [CrossRef] 
87. Skouteris, D.; Kyvelou, S. Inequalities and territorial justice: Maritime transport as a service of general interest. In Maritime Spatial Issues: Maritime Dimension of Territorial Cohesion, Maritime Spatial Planning, Sustainable Blue Growth; Kyvelou, S., Ed.; KRITIKI: Athens, Greece, 2016; pp. 472-483. (In Greek)

88. Healy, P. Urban Complexity and Spatial Strategies: Towards a Relational Planning for Our Times; Routledge: London, UK, 2006.

89. Innes, J.E.; Booher, D.E. Planning with Complexity: An Introduction to Collaborative Rationality for Public Policy; Routledge: Abingdon, UK, 2010.

90. White, C.; Halpern, B.S.; Kappel, C.V. Ecosystem service tradeoff analysis reveals the value of marine spatial planning for multiple ocean uses. Proc. Natl. Acad. Sci. USA 2012, 109, 4696-4701. [CrossRef] [PubMed]

91. Lombard, A.T.; Ban, N.C.; Smith, J.L.; Lester, S.E.; Sink, K.J.; Wood, S.A.; Jacob, A.L.; Kyriazi, Z.; Tingey, R.; Sims, H.E. Practical Approaches and Advances in Spatial Tools to Achieve Multi-Objective Marine Spatial Planning. Front. Mar. Sci. 2019, 6, 166. [CrossRef]

C 2019 by the authors. Licensee MDPI, Basel, Switzerland. This article is an open access article distributed under the terms and conditions of the Creative Commons Attribution (CC BY) license (http://creativecommons.org/licenses/by/4.0/). 